
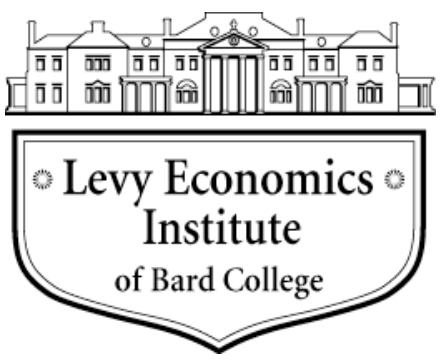

Working Paper No. 812

\title{
Time Use of Parents in the United States: What Difference Did the Great Recession Make?
}

by

Ebru Kongar*

Levy Economics Institute of Bard College

Günseli Berik**

University of Utah

\section{August 2014}

\footnotetext{
* kongare@dickinson.edu

** berik@economics.utah.edu
}

The Levy Economics Institute Working Paper Collection presents research in progress by Levy Institute scholars and conference participants. The purpose of the series is to disseminate ideas to and elicit comments from academics and professionals.

Levy Economics Institute of Bard College, founded in 1986, is a nonprofit, nonpartisan, independently funded research organization devoted to public service. Through scholarship and economic research it generates viable, effective public policy responses to important economic problems that profoundly affect the quality of life in the United States and abroad.

Levy Economics Institute

$$
\text { P.O. Box } 5000
$$

Annandale-on-Hudson, NY 12504-5000

http://www.levyinstitute.org

Copyright (C Levy Economics Institute 2014 All rights reserved 


\begin{abstract}
Feminist and institutionalist literature has challenged the "Mancession" narrative of the 2007-09 recession and produced nuanced and gender-aware analyses of the labor market and well-being outcomes of the recession. Using American Time Use Survey (ATUS) data for 2003-12, this paper examines the recession's impact on gendered patterns of time use over the course of the 2003-12 business cycle. We find that the gender disparity in paid and unpaid work hours followed a U-shaped pattern, narrowing during the recession and widening slightly during the jobless recovery. The change in unpaid work disparity was smaller than that in paid work, and was short-lived. Consequently, mothers' total workload increased under the hardships of the Great Recession and declined only slightly during the recovery.
\end{abstract}

Keywords: Economics of Gender; Economic Crises; Time Use; Unemployment; Unpaid Labor JEL Classifications: D13, J16, J64 


\section{INTRODUCTION}

In the immediate aftermath of the 2007-09 recession, job losses in the US disproportionately affected men, as the male-dominated manufacturing and construction sectors were hit first. In the face of high male unemployment, married women entered the labor force to supplement family income. Between 2007 and 2009, among married women, mothers with children under 18 experienced the largest increase in their participation rate (BLS 2013a). These shifts led to a rise in women's share of paid employment (payrolls), which had been relatively stagnant since the 1990s, and this share reached the 50-percent threshold for the first time in US history at the end of 2009 (BLS 2013a). These gender asymmetric employment patterns have been referred to in the popular media as "Mancession" or "He-cession" (Perry 2010; Thompson 2009).

Recent studies by heterodox and feminist economists challenged the mancession narrative of the 2007-09 recession and produced gender-aware research on the causes and outcomes of the recession and the subsequent policy responses. Nuanced analyses of the unemployment outcomes by demographic characteristics showed that labeling the 2007-09 recession as "Mancession" misidentifies the groups that were most adversely affected (Grown and Tas 2010). Hartmann et al. (2010) showed that by December 2009, single women experienced disproportionate job losses compared to married men (and women), while Grown and Tas (2010) found that African-American and Hispanic women experienced considerably greater job losses than White and Asian men. The unemployment rate for younger women (in the 16-24 age group) increased more than that of men ages 25 and over (Grown and Tas 2010). This scholarship has also emphasized the importance of incorporating in the analysis of the crisis the gendered institutions of markets and family and legacy of historical inequalities by gender, race and ethnicity. For instance, Dymski et al. (2013) argued that historical gender, racial and ethnic inequalities and discrimination in credit markets, such as redlining practices, played a role in the sub-prime lending and the subsequent financial crises. The gendersegregated employment structure of the US financial sector also played a role in shaping the outcomes of the financial crisis (Walby 2009; Lagarde 2010; Prügl 2012; Arestis et al. 2013). Albelda (2014) found that women, who historically have been overrepresented in public sector jobs, were disproportionately affected by state and local government budget cuts in response to declining tax revenues induced by the recession. 
Extending the analysis of the economic impact of the recession to include unpaid work and using American Time Use Survey (ATUS) data, feminist research also challenged the mancession narrative. Hartmann et al. (2010) showed that in 2008, individual unemployment doubled women's caregiving time while it increased men's caregiving time only slightly. Examining coupled parents' time allocation over the 2003-09 period, Morrill and Pabilonia (2012) argued that as the economy worsened, mothers were likely to have nonstandard (including weekend) employment hours and decreased the time they spent in enriching childcare activities (such as socializing and attending cultural events) but not the time they spent on basic childcare. Fathers increased their time in these activities. Focusing on married mothers and married fathers Berik and Kongar (2013) showed that the Great recession narrowed the gender gap in paid work hours, as fathers experienced disproportionate job losses and mothers entered into paid employment. The recession's impact on unpaid work disparity was weaker and came about largely because mothers spent less time on unpaid work. Fathers allocated most of their foregone labor market hours to leisure activities, rather than unpaid work. ${ }^{1}$ The pattern may be differentiated by household income level, as Khitarishvili and Kim (2014) show for a sample of women and men, rather than parents. Among men, only those in households below the federal poverty threshold increased the time they allocated to unpaid work.

The time use patterns of parents may have changed after 2010 in light of the prolonged stagnation of the job market following the end of the recession and the uneven recovery of jobs for women and men. In this paper, we apply trend analysis to ATUS data for 2003-2012 to examine the impact of the Great Recession on gender patterns of time use. Our primary concern is whether the combination of disproportionate job losses for men during the recession and entry of married mothers into the workforce resulted in more gender equitable sharing of the unpaid work burden, a trend that was stalled before the recession hit (Bianchi et al. 2005; Blau and Kahn 2007). With the benefit of additional years of data for recovery years, it is also possible to ascertain whether the gendered changes in time use during the recession settled.

Our methodology differs from Berik and Kongar (2013) in a number of ways: first, we define the business cycle by the extent of job losses as opposed to the NBER-dating of the recession as December 2007-June 2009. The job loss dating of the recession is more suitable to capturing the labor market effects of the recession on gendered time use in unpaid activities in the household. Thus, we date the recession as December 2007-December 2010 and the recovery as January 2011-December 2012. Second, we expand the sample of mothers and fathers to 
include unmarried partners as well as spouses. Third, we include additional categories of time use - the time spent in civic and religious activities, volunteer work and job search and secondary (passive) childcare activities to provide a more comprehensive analysis of time use.

\section{GENDER, RECESSIONS AND TIME USE}

Recessions increase the unpaid work burden in households as members compensate for lost income by increasing household production of goods and services (Greenwood and Hercowitz 1991; Burda and Hamermesh 2010; Aguiar et al. 2013). ${ }^{2}$ In developing country contexts, the burden of adjustment in households falls disproportionately on women (Benería and Feldman 1992; Elson 1995; Kaya Bahçe and Memiş 2013). There is also evidence that the "added worker" effect, that is, entry of women into the workforce to compensate for lost family income, increases women's relative work burden (Rubery 1988; Lim 2000; Elson 2012; Karamessini and Rubery 2013). The added-worker effects were also observed in the US recession of 2007-09 (Şahin et al. 2010; Berik and Kongar 2013; M.A. Starr 2014). Married-couple families in which only the wife engaged in paid work jumped from 6.9 percent of all married-couple families in 2008 to 8.4 percent in 2009 (BLS 2013a). Employment rates of women whose husbands were non-employed rose considerably during the recession and; women whose husbands stopped working during the recession were twice as likely to enter the labor force, particularly women with older children or no children and those in lower-income households (Mattingly and Smith 2010; M.A. Starr 2014).

The convergence in women's and men's labor force participation rates during the recession brought about a relatively small and short-lived decline in the relative unpaid work burden of mothers as fathers picked up childcare in the absence of mothers (Berik and Kongar 2013). One question of continuing interest is whether the recession has disrupted the stagnant trends in gendered unpaid work hours when assessed with additional years of evidence after its official end. The 2007-09 recession hit at a moment in US history when trends in mothers' and fathers' unpaid and paid work hours were relatively stagnant. After a considerable decline from the 1970 s to the early 2000s, the difference between (married or unmarried) mothers' and fathers' paid work hours narrowed, primarily due to an increase in mothers' paid work hours, as they entered the labor force (Bianchi et al. 2005). During this period, the time mothers and 
fathers spent in unpaid work also became similar as fathers increased their time in housework and gradually in childcare and mothers reduced their housework time (Bianchi et al. 2005).

Another question of interest is the effect of the adjustments in the gender division of unpaid and paid work on mothers' and fathers' total (paid and unpaid) workloads and, in turn, the time available for leisure and personal care. Burda et al. (2013) showed that in a number of affluent economies including the US, women and men had near equal workloads in the late twentieth and early twenty-first centuries, which they dubbed "iso-work." B Berik and Kongar (2013) showed that prior to the recession iso-work held for mothers and fathers but the recession led to a decline in fathers' relative work burden and disrupted the iso-work.

The focus of these studies has been primary activities, which are designated in answer to a question such as "What were you doing during this time period?" (Folbre 2006). ATUS collects data also on secondary childcare activities, during which children are supervised but not actively engaged. Recent research shows that secondary childcare activities may amount to a considerable number of hours, which understates the care work, especially of mothers, as this work may not be equitably shared between parents (Folbre and Yoon 2007). Using data from the 2003-2004 ATUS and a broad definition of secondary childcare to account for all time spent with children, Kalenkoski et al. (2007) find that on an average weekday, married mothers spent 3.6 hours, which is twice as much time as fathers, providing passive childcare. On a weekend day, mothers spent 5.4 hours per day providing secondary childcare compared to fathers who spent 4.7 hours per day. Similar results held in the UK (Kalenkoski et al. 2007). Using data from US time diaries from the 1975-1981 Time Use Longitudinal Panel and examining secondary childcare time in which children are being supervised, Nock and Kingston (1988) found that mothers' employment reduced their secondary childcare time more than their primary childcare time. This result is consistent with previous findings in the literature that mothers, whose paid work hours increased, protected their childcare time, even increasing it after 1985 (Bianchi et al. 2006; Ramey 2008; Ramey and Francis 2009).

Whether iso-work holds when secondary childcare is taken into consideration and how gender division of secondary childcare is affected by the recession have yet to be examined. Based on earlier evidence, we expect the recession and the subsequent rising employment of mothers due to the added-worker effect to have a stronger impact on mothers' secondary childcare time compared to their primary childcare time. During the recession, fathers are expected to take on secondary childcare in the absence of mothers, thus narrowing the gender 
gap in secondary childcare time. When paid work participation patterns are reversed during recovery, the gap in secondary childcare is also likely to be reversed.

\section{DATA AND METHODOLOGY}

We use the 2003-2012 ATUS data files to examine the impact of the Great Recession on gender differences in time use. Our sample consists of women and men in the 18-65 age group who live in the same household as their spouse or unmarried partner and at least one child under the age of 18 . Secondary childcare data are available only for the parents of children age 12 or younger. These mothers and fathers are not married to each other and, in the ATUS methodology it is not possible to directly obtain information on the time use of the respondent's partner. That said, this particular sample definition gets us as close as possible to inferring changes in the gender division of household labor, short of constructing matched couples based

on ATUS data. ${ }^{4}$ We expect our analysis to reflect the outcome of adjustments in the division of labor taking place in households of parents who are co-habiting with their spouse or unmarried partner. ${ }^{5}$

Following Aguiar et al. (2013) and Berik and Kongar (2013), we conducted a trend analysis to isolate the effect of the recession from the trends under way prior to the recession. Trend analysis entails estimating the trend for the recession years based on extrapolation from the January 2003-November 2007 period and identifying the recession effect as the difference between the observed and the trend values. Rather than adopting the recession-dating scheme of the National Bureau of Economic Research (NBER), which dates the recession period as December 2007-June 2009, we identify the recession by job loss. Figure 1 presents the unemployment rates for married mothers and fathers and shows that, after the recession hit in December 2007, married fathers' unemployment rates nearly doubled. Both unemployment rates peaked in 2010, at 6.8 percent for fathers and 6.3 percent for mothers, which were lower than the average rates for men and women (BLS 2012). Thus, based on the extent of job losses, we redefine three phases of the business cycle as follows: the expansion (January 2003November 2007) as the "prerecession;" the contraction (December 2007-December 2010) as the "recession;" and the expansion (January 2011-December 2012) as the "recovery."

To examine the iso-work hypothesis over the course of the business cycle, we calculate total work time as the sum of hours spent in paid and unpaid work. We define paid work as time 
spent on activities for pay and include in this category all time spent working in the market sector on main jobs, second jobs, and overtime, including any time spent commuting to/from work and time spent on work-related activities. Due to a combination of disproportionate job losses for men and entry of married women into the labor force in order to avoid loss of household income, we expect a decline in fathers' paid work hours, an increase in mothers' paid work hours and a subsequent narrowing of the gender gap in paid work hours.

Based on the third party principle, we distinguish among three alternative uses of nonmarket time: unpaid work, leisure, and personal care. Unpaid work comprises activities that one could pay a third party to perform, but for which one is not paid. We include in this category childcare, adult care, housework, and shopping.

Following common practice, we keep childcare and housework distinct categories. Parental childcare has an investment component and is likely to be more enjoyable than housework (Guryan et al. 2008; Connelly and Kimmel 2010). Moreover, recent studies show that childcare time behaves neither like housework nor like leisure; childcare is done more on weekdays and cannot be postponed, while housework can be delayed or foregone completely when time constraints intensify (Kimmel and Connelly 2007). Childcare comprises primary care activities of providing physical care for children; reading to, playing with and looking after children; doing arts and crafts, playing sports, talking with and listening to children; organizing, planning, and attending children's events; and picking up or dropping off children. We also examine secondary childcare for parents of children age 12 or younger, which is the time when children are supervised but not actively engaged. Evidence on earlier US recessions shows that fathers increased their childcare hours, although they reversed this pattern once their employment picked up (Casper and O'Connell 1998; US Census Bureau 2010). Accordingly, we expect fathers to pick up primary and secondary childcare, thus narrowing the gender difference in childcare hours. Since mothers tend to protect their primary childcare time when their paid work hours increase, we expect the narrowing effect to be stronger in the case of secondary childcare time (Bianchi et al. 2005). During recovery, as fathers' employment picks up and mothers' unemployment increases, these trends are likely to be reversed. 
Figure 1 US Annual Unemployment Rates Among Mothers and Fathers, 2001-12

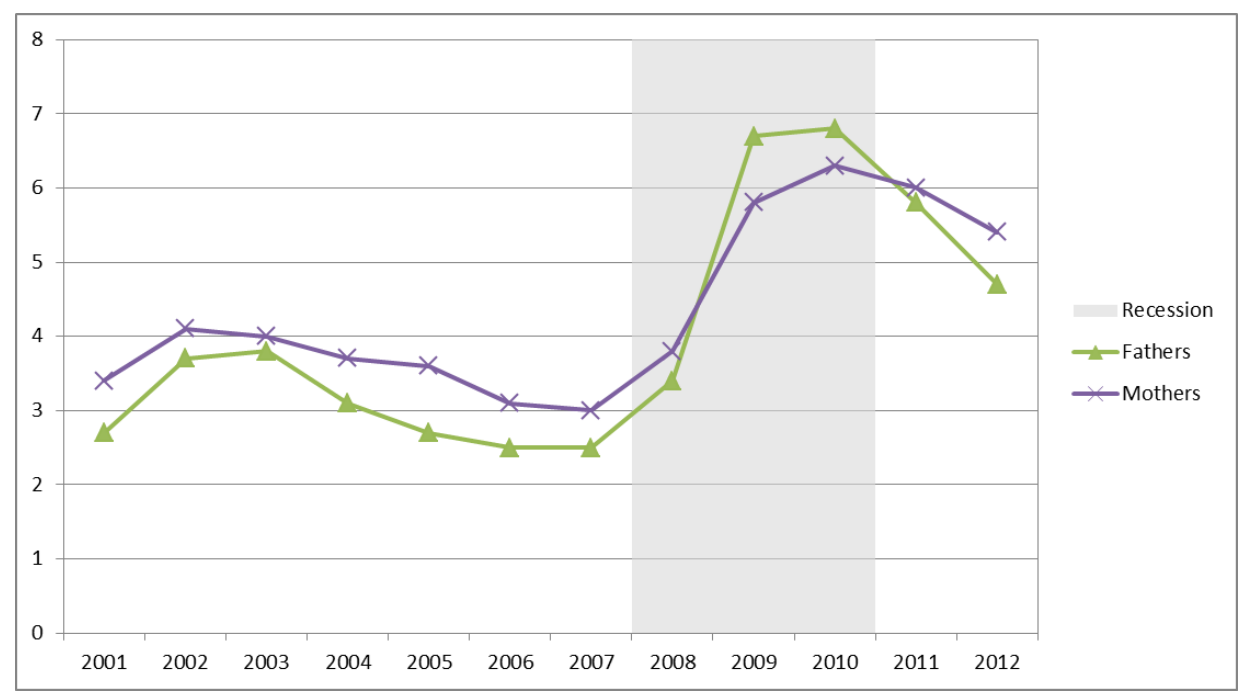

Source BLS (2013a, 2013b)

We include adult care as a separate category of care as, unlike childcare, it has no investment component. Adult care consists of providing or obtaining physical and medical care for adults (those 18 and over) and the waiting associated with these activities. These adults are either household members or reside in another household. Our sample includes mothers 45 to 56 years old who have elderly parents and dependent children, referred to as the "sandwhich generation" as they provide care for both their children and parents (Pierret 2006). The recession may create additional work caring for adults for both mothers and fathers as the spouse's or parents' health deteriorates because, for example, they delay seeking healthcare when they lose income, jobs, and health insurance, or simply due to the presence of an unemployed spouse in the household or other adults (e.g. adult children, parents) joining the household due to home closures or financial difficulty due to job loss. The absence of mothers in the household as they take on the breadwinner role may shift the adult care responsibilities on to the unemployed fathers.

Unlike childcare, housework does not have an investment component. We include in this category interior and exterior cleaning, laundry, and sewing. Unemployed fathers might pick up some of the housework as mothers increase their labor market hours and do less housework. Additional time spent in each activity may entail fathers substituting for mothers in household tasks (or vice versa, depending on the pattern prior to the recession).

We keep shopping as a distinct category, since some types of shopping, such as clothing purchases, may be enjoyable activities akin to leisure, while others, such as grocery shopping, 
may be more like housework. If households substitute home production for previously marketpurchased goods and services during a recession, shopping hours will decline. However, shopping hours will increase in a recession, if the unemployed seek to cut consumption spending by shopping longer hours for lower prices or if it behaves like a leisure activity (Aguiar and Hurst 2007). Aguiar et al. (2013) find that in 2009 and 2010, men allocated a small portion ( 7 percent) of their foregone market hours to obtaining goods and services. Shopping hours, however, declined for a combined sample of women and men, indicating that women spent less time shopping during the recession. Berik and Kongar (2013) also find that the recession led to a decline in mothers' shopping hours. Their results show that the recession did not have a statistically or economically significant effect on fathers' shopping hours.

Accordingly, we expect the recession to reduce the time mothers spend shopping for goods and services.

Leisure comprises activities that one cannot pay someone else to do. In this category we include television watching, listening to music, socializing with friends, and other recreational activities. Personal care comprises sleeping, own medical care, and other activities related to satisfying needs. Like leisure, one cannot pay a third party to do these activities, but, unlike leisure, at least some personal care activities are necessary for survival. Time-use patterns prior to 2007 suggest that women in the US spent more time on personal care activities than men, while men spent more time on leisure activities than women (Aguiar and Hurst 2007). In 2009 and 2010, men allocated a third of their foregone hours to leisure and personal care activities. Mothers will finance the increase in their paid work hours by cutting down unpaid work, leisure and/or personal care hours. Therefore, we expect a convergence in the gender disparity in personal care and leisure hours.

The "Other" category includes the time spent on looking for a job, which is expected to increase more for fathers who experienced disproportionate job losses than mothers. We also include in the Other category time spent on civic and religious activities. Aguiar et al. (2013) find that a combined sample of men and women allocate 6 percent of their time to civic and religious activities during the recession. We investigate whether there is a gender difference in the recession's impact on civic and religious activities. Volunteering is the final activity we include in the Other category. In 2009, 1.6 more million people volunteered in the US compared to the previous year, and1.2 million of these volunteers were women (Corporation for National 
and Community Service 2010). Thus, we expect the time mothers spent volunteering to increase during the recession, more than fathers.

The time unit in the analysis is weekly hours, which are the weighted sum of weekend and weekday values according to standard practice: we calculated the daily time use for each activity separately for weekdays and weekends, multiplied weekend values by two, multiplied weekday values by five, and added the two sums to obtain the weekly hours spent in each activity. For nationally representative results, we weight observations by ATUS sample weights.

To isolate the recession's impact from the trend established in the expansion period preceding the recession, we fit a linear trend for each time-use category based on individuallevel data aggregated at the monthly level over the January 2003-November 2007 period and extrapolate the values for December 2007-December 2012. The trend analysis consists of ordinary least squares (OLS) estimation, where the dependent variable is the extrapolated weekly hours spent in each time-use category and the independent variables are a trend variable and a dummy variable for the December 2007-December 2010 period. Any difference between the observed and trend values can be attributed to the recession as the cycle effect. In a similar manner, we ascertain the cycle effect for the recovery period. We are fairly confident that the trend analysis based on simple linear extrapolation approximates the long-run trends, even if it is based on a rather brief period. As Aguiar et al. (2013) conclude, trend analysis based on simple linear extrapolation for the 2003-10 period yields results similar to an alternative methodology that uses cross-state variation in paid work hours. In addition, the time-use values for the prerecession period are fairly consistent with the values reported in earlier studies that go back in time (Guryan et al. 2008; Connelly and Kimmel 2010; Bianchi 2011).

\section{EMPIRICAL FINDINGS}

\subsection{Job Loss and the Added Worker Effect}

We begin the empirical analysis with descriptive results on the labor force status and paid work hours of mothers and fathers who reside in the same household with their partners, using ATUS data. These results are presented in Table 1, which shows that the recession brought closer the employment status distributions of married mothers and fathers. These patterns were reversed during recovery. Specifically, the upper panel of Table 1 shows that during the recession, the proportion of mothers who were out of the labor force declined by 3.7 percentage points. Most 
of the mothers who entered the workforce found employment (an increase by 1.6. percentage points in the proportion of full-time employed and a 0.3 percentage-point increase in the proportion of part-time employed). Unemployment among mothers increased by 1.7 percentage points. Hence, the ATUS data reflect the added-worker effects between December 2007 and December 2010. During the recession, fathers' unemployment increased by 3.2 percentage points. The proportion of fathers who were out of the labor force also increased slightly by 0.2 percentage point. Among the employed fathers, full-time employment declined and part-time employment increased. During recovery, mothers' labor force participation dropped close to its prerecession level. Proportion of full-time and part-time employed mothers declined. As mothers dropped out of the labor force, their unemployment rate declined slightly by 0.3 percentage point. Fathers' unemployment rate declined by 1.8 percentage points and the proportion out of the labor force increased by 1.2 percentage points.

The lower panel in Table 1 shows that paid work hours followed a similar pattern. Specifically, the recession occasioned an increase in mothers' weekly hours and a decline in fathers' weekly hours. ${ }^{6}$ During the recovery period, full-time employed fathers' paid work hours went up to their prerecession level, while full-time employed mothers' paid work hours continued to increase after the recession. Part-time employed mothers' and fathers' paid work hours declined. 
Table 1 Labor Market Status of Mothers and Fathers Over the 2003-12 Business Cycle

\begin{tabular}{|c|c|c|c|c|c|c|c|c|}
\hline & \multicolumn{4}{|c|}{ Mothers } & \multicolumn{4}{|c|}{ Fathers } \\
\hline & $\begin{array}{l}\text { Full-time } \\
\text { employed }\end{array}$ & $\begin{array}{l}\text { Part-time } \\
\text { employed }\end{array}$ & Unemployed & $\begin{array}{l}\text { Out of } \\
\text { the labor } \\
\text { force }\end{array}$ & $\begin{array}{l}\text { Full-time } \\
\text { employed }\end{array}$ & $\begin{array}{l}\text { Part-time } \\
\text { employed }\end{array}$ & Unemployed & $\begin{array}{l}\text { Out of } \\
\text { the labor } \\
\text { force }\end{array}$ \\
\hline
\end{tabular}

A. Distribution by employment status (percent)

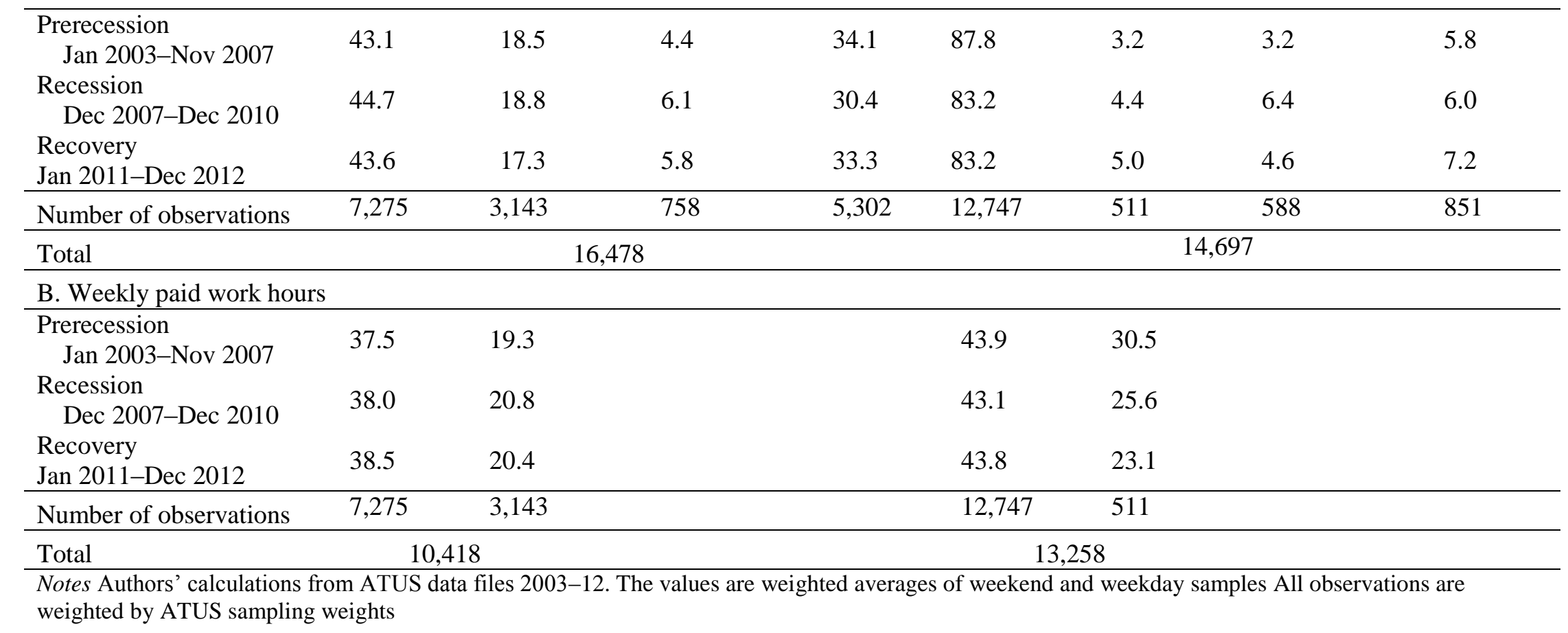




\subsection{Trend Analysis of the Gender Disparity in Paid and Unpaid Work Hours}

Figure 2 provides descriptive results for the time series analysis of the gender difference (mothers-fathers) in work hours. The year-to-year estimates of the gender difference in paid work hours are denoted by the solid line, and the dotted line shows the trend, extended linearly over the recessionary period and the recovery period. In 2003, fathers spent considerably more time (18.5 more hours per week) working for pay than mothers. Between 2007 and 2010, the gap narrowed to under 14 hours per week but reverted to 18 hours during the recovery period of 2010 and 2012. Thus, in the course of the 2007-2012 period, the gender difference in paid work hours exhibited an inverted U-shape pattern, narrowing during the recession and widening during recovery, both in absolute terms and also relative to trend.

Was the trend in the gender gap in paid work paralleled in unpaid work over the 20072012 period? In other words, was there a U-shaped pattern in the gender difference in unpaid work hours, which would be expected if fathers picked up unpaid work hours as mothers substituted market hours for unpaid hours? Prior to the recession, women spent more time on unpaid work compared to men (Berik and Kongar 2013). Aguiar et al. (2013) showed that during the recession mothers and fathers allocated an equal proportion - about a third — of their foregone market hours to unpaid work, which suggests a weak U-shaped pattern over the course of the 2007-2012 period. Figure 3 shows that there was indeed a U-shaped pattern in the gender difference (mothers-fathers) in weekly unpaid work hours in absolute terms and also relative to the trend, and, as expected, this pattern was not as pronounced as the inverted U-shaped pattern in paid work. 
Figure 2 Gender Difference (Mothers-Fathers) in Weekly Paid Work Hours, 2013-2012

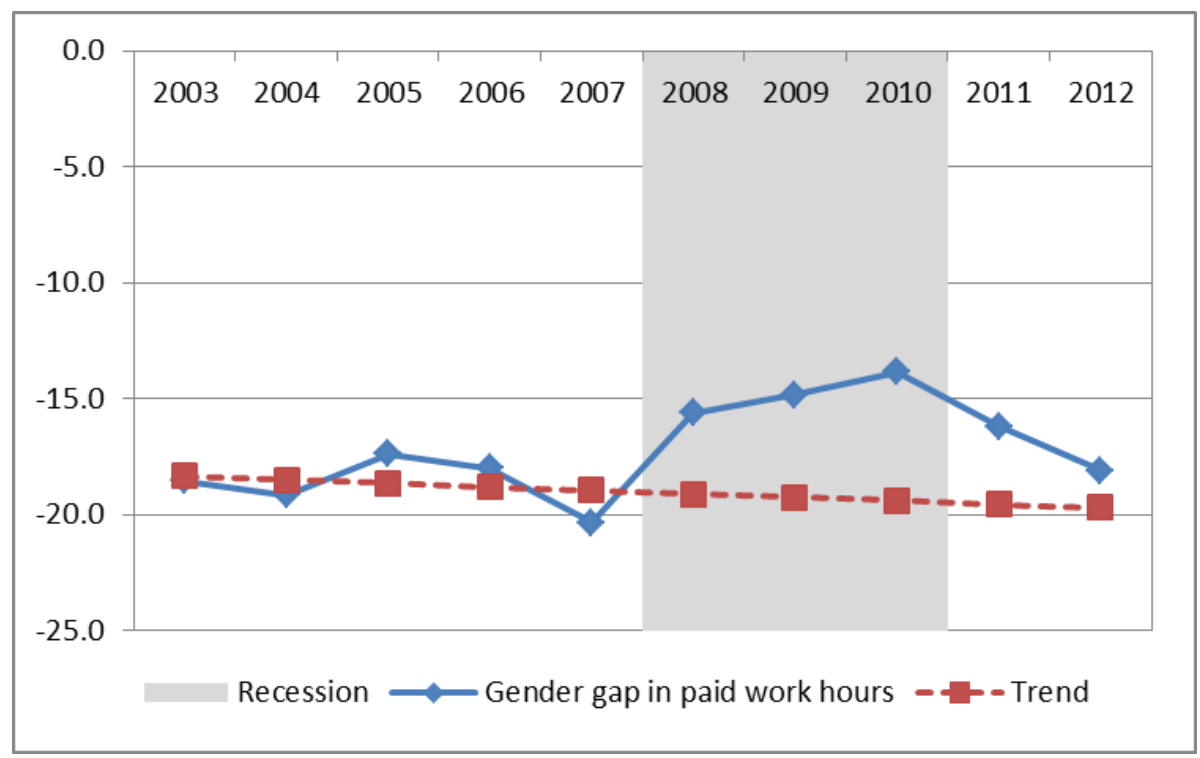

Notes: The sample consists of 20,533 mothers and 17,233 fathers. All observations are weighted by ATUS sampling weights.

Figure 3 Gender Difference (Mothers-Fathers) in Weekly Unpaid Work Hours, 2013-2012

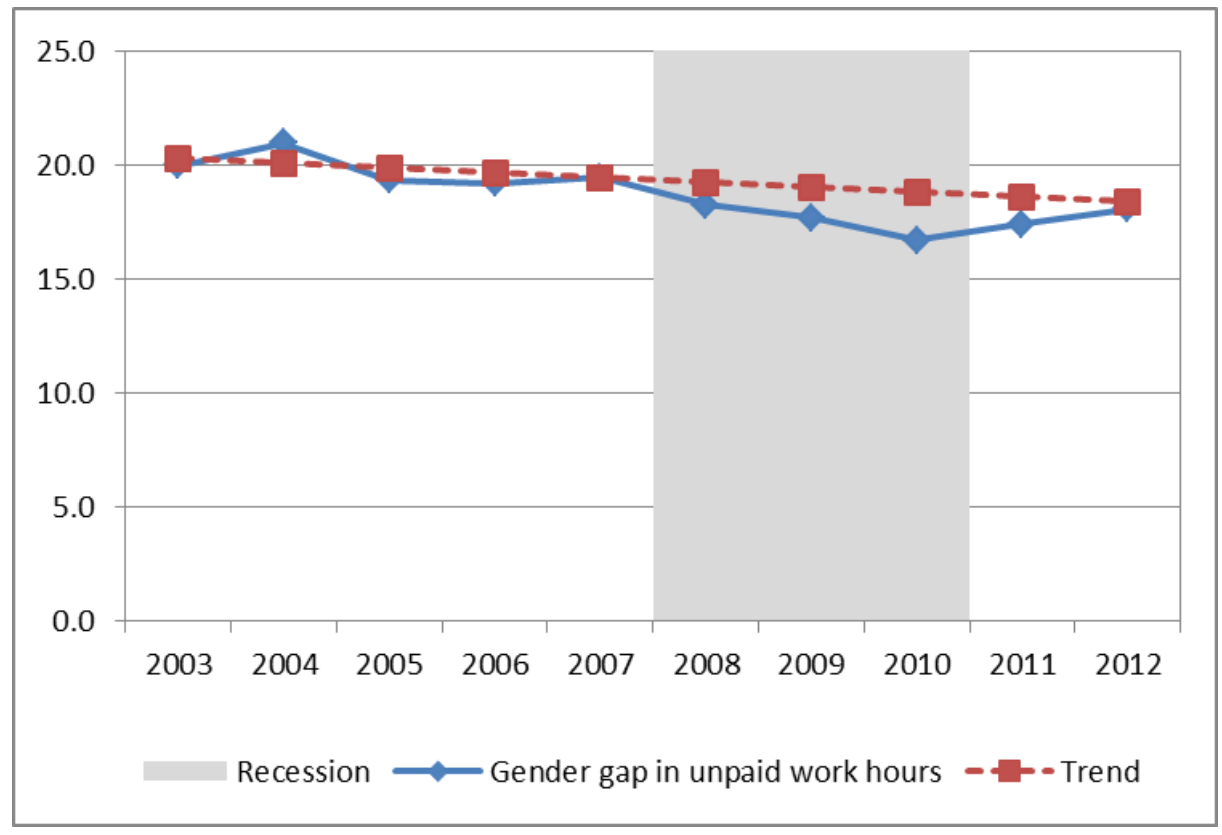

Notes See notes to Figure 2

To quantify the impact of the recession on gender differences in time use, we average the gender differences over the prerecession (January 2003-November 2007), recession (December 2007December 2010) and recovery (January 2011-December 2012) stages of the business cycle and calculate the differences across periods. This aggregation also helps us smooth out potential 
measurement error in year-to-year variations. Table 2 reports these results. We present the gender difference in time use in the prerecessionary period in column 1. Columns 2 and 3 show the changes in the gender difference across time periods. Columns 4 and 5 report the "detrended" results or "cycle effects," where we calculate and isolate the portion of the changes that are attributable to the continuation of prerecessionary trends.

The results of Table 2 show similar patterns to the ones illustrated by Figures 2 and 3 . There is a large narrowing of the gender gap in paid work hours in absolute terms and also relative to the trend during the recession, and this is reversed during recovery. In particular, between the prerecessionary and the recessionary periods, the gender difference in paid work hours narrowed by 3.72 hours per week (column 2). There was an even larger decline relative to the trend: gender difference in paid work hours narrowed by 4.32 hours per week between the recessionary period and the prerecessionary period (column 4). However, the gender difference widened by 2.21 hours per week between the recessionary period and the recovery period (column 3). Most ( 82 percent) of this change (-1.83 hours per week) was due to the cycle effect (column 5). Thus, these results are consistent with the inverted U-shaped pattern of the gender difference in paid work hours illustrated in Figure 2. 
Table 2 Trend Analysis of Gender Differences in Time Allocation, 2003-12 (Weekly Hours)

\begin{tabular}{|c|c|c|c|c|c|}
\hline & Average & \multirow{2}{*}{$\frac{\text { Observed change }}{(2)}$} & \multicolumn{3}{|c|}{ Cycle effect (Detrended change) } \\
\hline & $(1)$ & & (3) & $(4)$ & $(5)$ \\
\hline & Prerecession & $\begin{array}{c}\text { Recession vs. } \\
\text { Prerecession }\end{array}$ & $\begin{array}{c}\text { Recovery vs. } \\
\text { Recession }\end{array}$ & $\begin{array}{l}\text { Recession vs. } \\
\text { Prerecession }\end{array}$ & $\begin{array}{c}\text { Recovery vs. } \\
\text { Recession }\end{array}$ \\
\hline \multirow[t]{2}{*}{ Paid work } & $-18.64 * * *$ & $3.72 * * *$ & $-2.21 *$ & $4.32 * * *$ & -1.83 \\
\hline & $(0.57)$ & $(0.93)$ & $(1.22)$ & $(0.93)$ & $(1.22)$ \\
\hline \multirow[t]{2}{*}{ Unpaid work } & $19.86 * * *$ & $-2.42 * *$ & 0.28 & $-1.59 * *$ & 0.81 \\
\hline & $(0.46)$ & $(0.75)$ & $(0.95)$ & $(0.75)$ & $(0.95)$ \\
\hline \multirow[t]{2}{*}{ Housework } & $9.74 * * *$ & $-1.13 * *$ & $1.23 * *$ & -0.45 & $1.66 * *$ \\
\hline & $(0.30)$ & $(0.48)$ & $(0.62)$ & $(0.48)$ & $(0.62)$ \\
\hline \multirow[t]{2}{*}{ Childcare } & $7.80 * * *$ & $-1.02 * *$ & -0.50 & $-1.10 * *$ & -0.55 \\
\hline & $(0.28)$ & $(0.45)$ & $(0.57)$ & $(0.45)$ & $(0.57)$ \\
\hline \multirow[t]{2}{*}{ Adultcare } & -0.10 & -0.08 & -0.28 & 0.18 & -0.12 \\
\hline & $(0.13)$ & $(0.21)$ & $(0.30)$ & $(0.21)$ & $(0.30)$ \\
\hline \multirow[t]{2}{*}{ Shopping } & $2.42 * * *$ & -0.19 & -0.17 & -0.21 & -0.18 \\
\hline & $(0.20)$ & $(0.32)$ & $(0.42)$ & $(0.32)$ & $(0.42)$ \\
\hline \multirow[t]{2}{*}{ Total work } & $1.22 * *$ & 1.30 & $-1.93^{*}$ & $2.74 * *$ & -1.02 \\
\hline & $(0.52)$ & $(0.84)$ & $(1.05)$ & $(0.84)$ & (1.06) \\
\hline \multirow[t]{2}{*}{ Nonwork } & -0.11 & $-1.69 *$ & 0.88 & $-3.68 * * *$ & -0.39 \\
\hline & $(0.56)$ & $(0.91)$ & $(1.22)$ & $(0.91)$ & $(1.23)$ \\
\hline \multirow[t]{2}{*}{ Personal care } & $3.13 * * *$ & -0.27 & -0.77 & $-1.42 * *$ & $-1.50 * *$ \\
\hline & $(0.33)$ & $(0.53)$ & $(0.68)$ & $(0.53)$ & $(0.68)$ \\
\hline \multirow[t]{2}{*}{ Leisure } & $-3.24 * * *$ & $-1.42 * *$ & $1.65 *$ & $-2.26^{* *}$ & 1.11 \\
\hline & $(0.44)$ & $(0.71)$ & $(0.92)$ & $(0.72)$ & $(0.93)$ \\
\hline \multirow[t]{2}{*}{ Other } & $0.51 *$ & -0.01 & 0.35 & 0.57 & 0.72 \\
\hline & $(0.29)$ & $(0.47)$ & $(0.60)$ & $(0.47)$ & $(0.60)$ \\
\hline \multirow[t]{2}{*}{ Civic \& religious } & $0.40 * * *$ & -0.04 & 0.03 & -0.22 & -0.08 \\
\hline & $(0.11)$ & $(0.18)$ & $(0.24)$ & $(0.18)$ & $(0.24)$ \\
\hline \multirow[t]{2}{*}{ Volunteer work } & 0.29 & 0.18 & 0.09 & $1.01 * *$ & 0.63 \\
\hline & $(0.21)$ & $(0.33)$ & $(0.40)$ & $(0.33)$ & $(0.40)$ \\
\hline \multirow[t]{2}{*}{ Job search } & $-0.18 * * *$ & $-0.15^{*}$ & $0.22 *$ & $-0.22 * *$ & 0.17 \\
\hline & $(0.05)$ & $(0.08)$ & (0.12) & $(0.08)$ & $(0.12)$ \\
\hline
\end{tabular}

Notes The sample consists of 16,478 mothers and 14,697 fathers. Standard errors are in parentheses. *****,* denote statistical significance at the 1, 5, and 10 percent levels, respectively. Jan. 2003-Nov. 2007 is the prerecession period; Dec. 2007-Dec. 2010 is the recession period; and Jan. 2011-Dec. 2012 is the recovery period. Column 1: the observed prerecession mother-father disparity in time spent in each activity; Column 2: the change in the disparity between the recession and the prerecession period. Column 3: the change in the disparity between the recovery and the recession period; Column 4-5: detrended effects of the recession obtained by subtracting the respective trend values from the observed values in Columns 2-3. 
The changes in the gender difference in unpaid work parallel those in the gender difference in paid work and, as expected, are smaller in magnitude. Specifically, the gender difference in unpaid work narrowed by 2.42 hours per week during the recession (column 2).

The cycle effect accounts for the majority (1.59 hours or 66 percent) of this decline. There was a small but statistically insignificant increase in the gap from the recessionary period to the recovery. The cycle effect shows a larger but also statistically insignificant increase in the gap by 0.81 hour per week. These results are consistent with the U-shaped pattern illustrated in Figure 3, which is considerably less pronounced than the inverted U pattern for paid work hours, as confirmed by the statistically insignificant changes.

Similar to unpaid work, gender differences in the use of nonwork (leisure and personal care) time narrowed during the recession (column 2) but only weakly widened during the recovery (column 3). Specifically, controlling for trend, the gender difference in nonwork time narrowed by 3.68 hours per week between the prerecessionary and the recessionary period, but the change over the recovery was negligible. Focusing on the effect of the cycle on the components of nonwork time indicates that, controlling for prerecessionary trends, the gender difference in leisure time followed a pattern similar to unpaid work, while the personal care hours gap declined about one hour and a half during both the recession and the recovery. The narrowing of the gender gap in leisure time during the recession and the reversal of this trend during recovery is consistent with the likely changes in fathers' leisure hours over the course of the business cycle: fathers' leisure hours may increase during the recession as they allocate a portion of their foregone hours to leisure and subsequently decrease as fathers' paid work hours increase during recovery. The gap in personal care hours also narrowed during the recession, and continued to narrow during recovery, which likely reflects an increase in fathers' personal care hours during recovery.

\subsection{End of the Double Day?}

Our findings show that prior to the recession, mothers' total workload was on average 1.22 hours more per week than fathers (column 1). In other words, on an average day, mothers worked 12 more minutes than fathers, which adds up to an hour and 24 minutes per week. While this difference is statistically significant, its magnitude is even smaller than the 20-minute difference that led to the end of the double day argument made by Konigsberg (2011), which she suggests is a signal of the end of the double day or achievement of equal workloads (iso- 
work) by mothers and fathers. This argument raises the question of what the threshold might be for the achievement of iso-work. In this paper, we treat this statistically significant difference of an additional hour and fifteen minutes per week as an important shortfall from the mothers' perspective.

How did the recession affect the relative workload among parents? Berik and Kongar (2013), who defined the recession period as December 2007-June 2009, showed that the recession increased the workload of married mothers relative to married fathers. Our results in this paper are consistent with that finding. Column 4 of Table 2 shows that the recession led to a 2.74-hour increase in the gender gap in total work hours (mothers working 2.74 more hours relative to fathers). This gap narrowed by 1.02 hours per week during the recovery, but this result is not precisely estimated.

\subsection{Mothers' and Fathers' Time Use}

Tables 3 and 4 present the results of the trend analysis for mothers and fathers, respectively. These results underlie the patterns in gender differences in time use presented in Table 2. For brevity, we discuss only the cycle effects that reflect the changes in time use that are not attributable to continuation of prerecessionary trends.

Narrowing of the gender disparity in paid work during the recession is due to a combination of an increase in mothers' paid work hours by 1.34 hours per week (column 2 of Table 3) and a decline in fathers' paid work hours by 2.98 hours per week (column 2 of Table 4). These findings are consistent with mothers' entry into the workforce (drop in the share of mothers who are out of the labor force) and increase in percentage of fathers who are out of the labor force (Table 1).

The narrowing gap in unpaid work hours by 1.10 hours per week during the recession was driven by a combination of a small ( 0.81 hour per week) decline in mothers' unpaid hours and a small increase in fathers' unpaid work hours by 0.77 hour per week (column 4 of tables 3 and 4). Neither change is precisely estimated, but their combination leads to a significant decline in the gender difference in unpaid work hours. During recovery the trends in mothers' and fathers' paid work hours (column 5 of Table 3 and Table 4) are reversed, albeit these results are also statistically weak. Together with the findings on paid work, the picture that emerges is as follows: As mothers entered paid employment, they reduced their unpaid work burden slightly, and some of this work was picked up by unemployed fathers. As fathers' paid work 
hours declined due to the recession, their leisure and personal care hours increased (column 4 of Table 4). 
Table 3 Trend Analysis of Mothers' Time Allocation, 2003-12 (Weekly Hours)

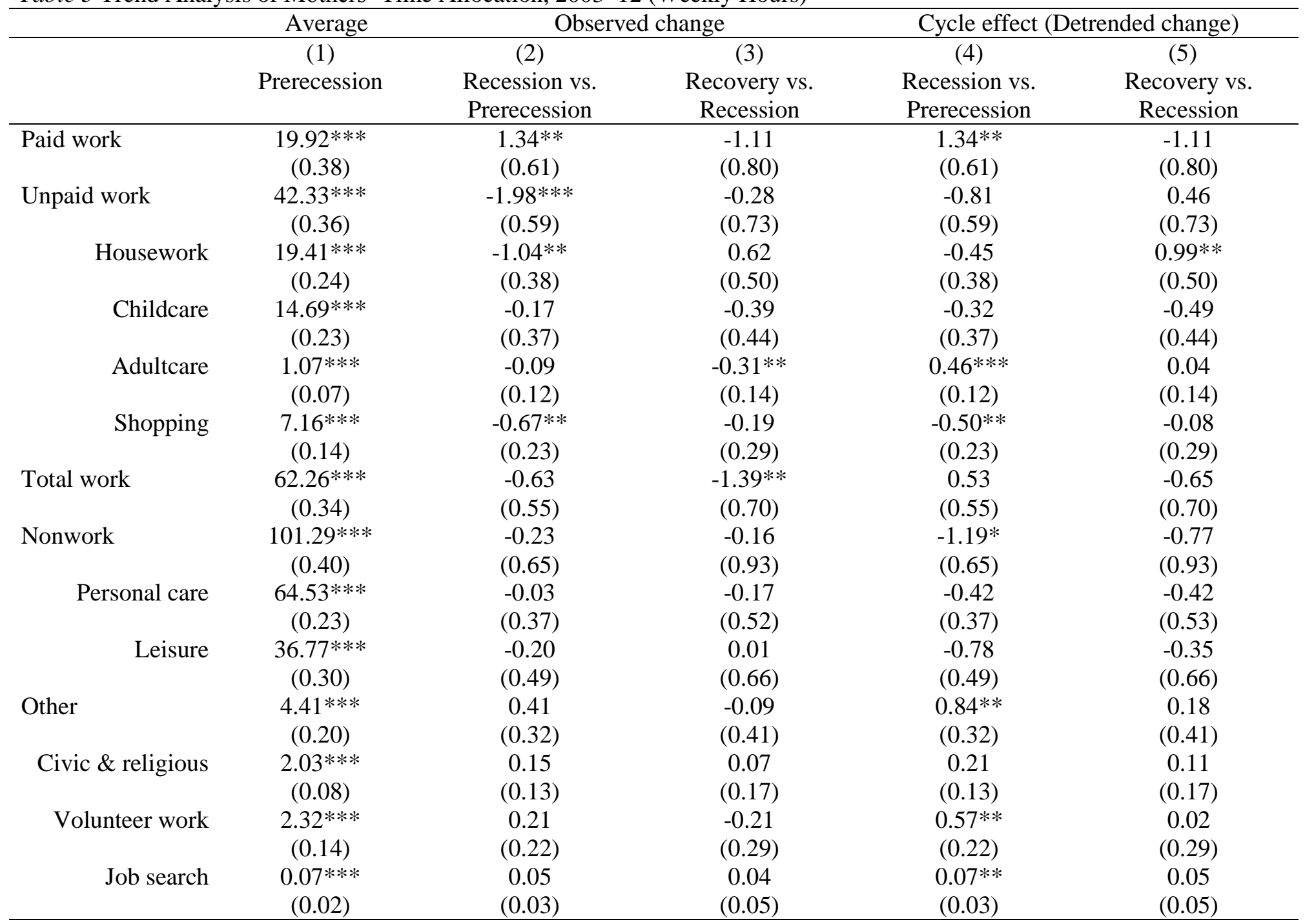

Notes Table 3 presents the changes in mothers' time use that underlie the changes in time-use gaps presented in Table 2. See notes to Table 2 for column definitions. 
Table 4 Trend Analysis of Fathers' Time Allocation, 2003-12 (Weekly Hours)

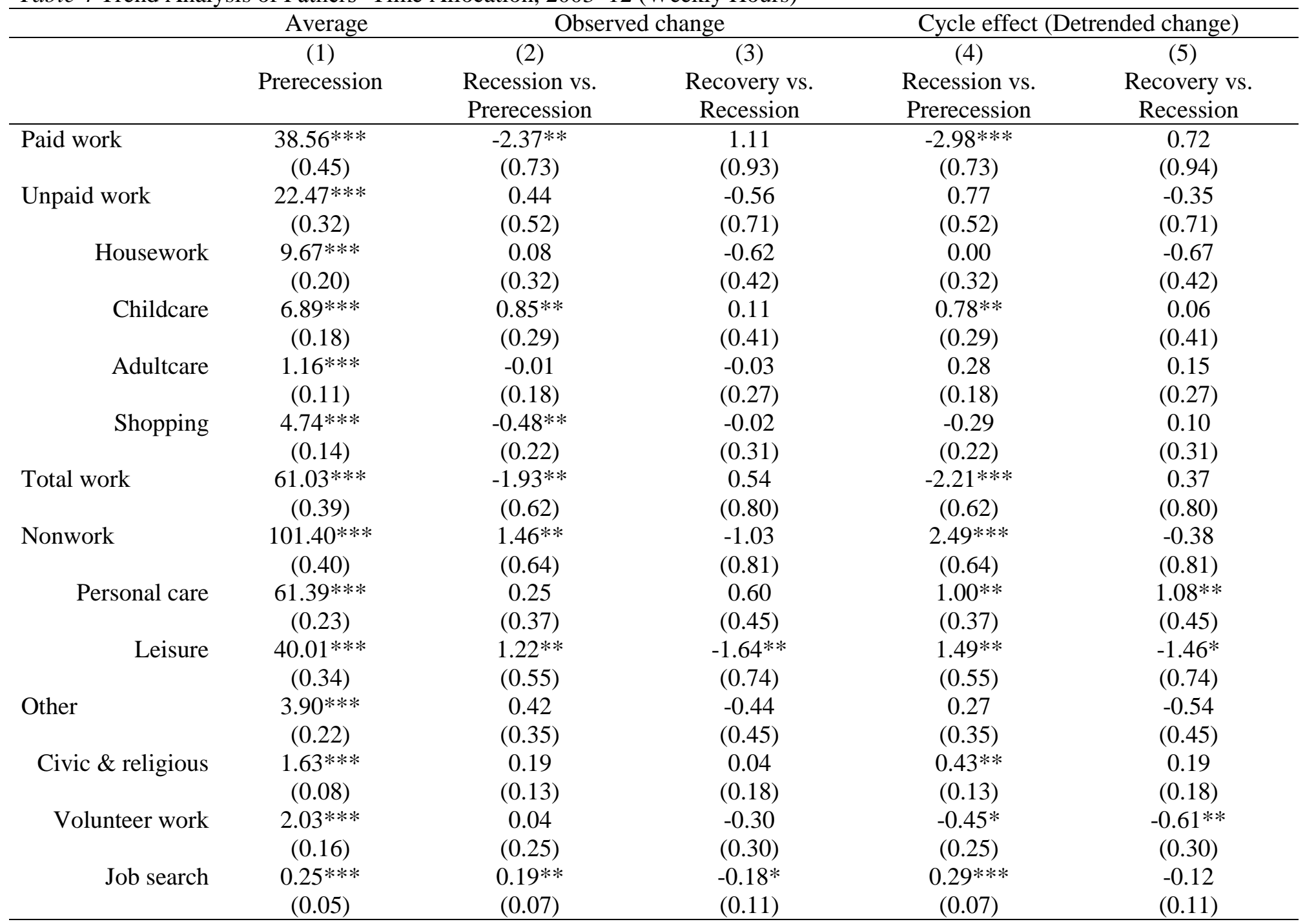

Notes Table 4 presents the changes in fathers' time use that underlie the changes in time-use gaps presented in Table 2. See notes to Table 2 for column definitions. 
During the weak recovery, the pattern in leisure time was reversed, while that in personal care hours continued. The effect of the recession on mothers' leisure and personal care hours was negative but statistically and economically insignificant during the recession and recovery.

\subsection{A closer Look at Unpaid Work and Other Activities}

To examine whether compositional shifts underlie the recession's effect on unpaid work, we conduct the trend analysis for each category of unpaid work. This analysis indicates that the narrowing of the unpaid work gap during the recession was driven by the patterns of childcare, housework and shopping. In particular, controlling for trend, the gender gap declined in all subcategories of unpaid work, except adult care, during the recession, but the only statistically significant change was in childcare (column 5): The gender difference in childcare hours narrowed by 1.10 hours per week, which accounts for 69 percent of the cycle effect on unpaid work. The increase in the unpaid work gap during recovery is driven by the trend in housework, which widened by 1.66 hours per week, with no other notable changes in other unpaid household tasks. This result suggests that in childcare the change towards more egalitarian distribution of childcare hours has settled in.

In sum, the U-shaped gender pattern in unpaid work over the course of the business cycle was driven by two activities: childcare and housework. The detrended decline in the gender disparity in childcare hours was due to the increase in fathers' childcare hours during the recession while mothers' childcare hours were virtually unchanged (Tables 3 and 4, column 4). These results are consistent with previous findings in the literature that in 2009 fathers spent more time providing childcare (Morrill and Pabilonia 2012) and that mothers whose paid work hours increased protected their childcare time (Bianchi, Robinson and Milkie 2006). There was no change in housework arrangements during the recession. During the recovery, however, the gender disparity in housework increased, primarily due to an increase in mothers' housework hours (Table 3, column 5).

The recession increased the time mothers spent providing adult care by about half an hour per week, which is a small but a precisely estimated change. Plausible explanations for this outcome include the presence of the unemployed spouse/partner at home, other adults joining the household (e.g. adult children or parents joining the household due to increasing home closures) or increased need for the spouse's care due to health effects of the recession. Mothers also reduced the time they spent purchasing goods and services, also by half an hour, which 
likely reflects belt-tightening due to declining household income. The recovery did not have a notable impact on either mothers' or fathers' adult care or shopping hours. The stagnant outcomes during the recovery suggest that the changes during the recession have settled: mothers perform slightly more adult care and make do with slightly less shopping.

The "other" time use category includes civic and religious activities, volunteer work and time allocated to job search. Aguiar, Hurst and Karabarbounis (2013) found that men and women increased the time they allocated to civic and religious activities and job search during the NBER-dated recession. We find that, during the recession, the only statistically significant and economically notable changes in gender gaps are in time spent at volunteer work and job search: The gap in volunteer work increased by an hour, but its increase during the recovery is not precisely estimated. Underlying the rise in gender disparity in volunteer work was increased volunteer hours by mothers, while fathers spent less time in volunteer work (Tables 3 and 4 column 4). The gap in job search narrowed by 0.22 hour per week during the recession, driven primarily by fathers' job search activity, and declined (albeit not significantly) during recovery.

\subsection{Secondary Childcare}

Table 5 presents the secondary childcare results for the sample of mothers and fathers with children younger than 13 (hereafter younger children). For brevity, we focus on results pertaining to selected work categories. ${ }^{7}$ Before the recession, mothers of younger children spent 21.1 fewer hours in paid work compared to fathers and, when only primary childcare activities are taken into account, spent 21.6 hours more doing unpaid work than fathers. In these circumstances, iso-work held for mothers and fathers of younger children before the recession: the gender difference in total workload was negligible (0.51 hour per week) and statistically insignificant. When secondary childcare is included, however, the gender difference in total work hours jumps to 17.8 hours per week. The gender difference in total childcare hours increases from 9 to 26 hours per week, widening the gender gap in weekly unpaid work hours from 21.6 hours to 38.9 hours per week. Thus, this analysis shows that secondary childcare is predominantly the mothers' responsibility, and when it is included in the analysis, we observe that iso-work did not hold for the parents of younger children, before the recession. 
Table 5 Trend Analysis of Time Allocation for Parents of Children Younger than 13, 2003-12 (Weekly Hours)

\begin{tabular}{|c|c|c|c|c|c|}
\hline & \multirow{2}{*}{$\frac{\text { Average }}{(1)}$} & \multicolumn{2}{|l|}{ Observed change } & \multicolumn{2}{|c|}{ Cycle effect (Detrended change) } \\
\hline & & $(2)$ & (3) & (4) & (5) \\
\hline & Prerecession & $\begin{array}{l}\text { Recession vs. } \\
\text { Prerecession }\end{array}$ & $\begin{array}{l}\text { Recovery vs. } \\
\text { Recession }\end{array}$ & $\begin{array}{l}\text { Recession vs. } \\
\text { Prerecession }\end{array}$ & $\begin{array}{c}\text { Recovery vs. } \\
\text { Recession }\end{array}$ \\
\hline \multicolumn{6}{|c|}{ Gender difference (Mothers - Fathers) } \\
\hline \multirow[t]{2}{*}{ Paid work } & $-21.06^{* * *}$ & $4.58 * * *$ & $-2.25 *$ & $6.15^{* * *}$ & -1.26 \\
\hline & $(0.54)$ & $(0.87)$ & $(1.14)$ & $(0.87)$ & $(1.15)$ \\
\hline \multirow[t]{2}{*}{ Unpaid work } & $21.57 * * *$ & $-3.07 * * *$ & 0.86 & $-2.52 * * *$ & 1.21 \\
\hline & $(0.46)$ & $(0.73)$ & $(0.94)$ & $(0.73)$ & $(0.94)$ \\
\hline \multirow[t]{2}{*}{ Primary childcare } & $8.99 * * *$ & $-1.09 * *$ & -0.41 & $-0.92 * *$ & -0.30 \\
\hline & $(0.27)$ & $(0.44)$ & $(0.57)$ & $(0.44)$ & $(0.57)$ \\
\hline \multirow[t]{2}{*}{ Total childcare } & $26.30 * * *$ & $-3.79 * * *$ & -0.85 & $-3.40 * * *$ & -0.60 \\
\hline & $(0.62)$ & $(1.00)$ & $(1.30)$ & $(1.00)$ & $(1.30)$ \\
\hline \multirow{4}{*}{$\begin{array}{l}\text { Unpaid work inc. } \\
\text { secondary childcare } \\
\text { Total work }\end{array}$} & $38.87 * * *$ & $-5.77 * * *$ & 0.42 & $-5.01 * * *$ & 0.90 \\
\hline & $(0.78)$ & $(1.26)$ & $(1.65)$ & $(1.26)$ & $(1.64)$ \\
\hline & 0.51 & $1.52 * *$ & -1.40 & $3.63^{* * *}$ & -0.05 \\
\hline & $(0.47)$ & $(0.76)$ & $(0.97)$ & $(0.76)$ & $(0.97)$ \\
\hline \multirow{3}{*}{$\begin{array}{l}\text { Total work inc. } \\
\text { secondary childcare }\end{array}$} & $17.82 * * *$ & -1.19 & -1.83 & 1.14 & -0.36 \\
\hline & $(0.60)$ & $(0.97)$ & $(1.29)$ & $(0.96)$ & $(1.28)$ \\
\hline & \multicolumn{5}{|c|}{ Mothers } \\
\hline \multirow[t]{2}{*}{ Paid work } & $19.32 * * *$ & $1.66 * *$ & -0.95 & $1.67 * *$ & -0.95 \\
\hline & $(0.36)$ & $(0.58)$ & $(0.80)$ & $(0.58)$ & $(0.80)$ \\
\hline \multirow{2}{*}{ Unpaid work } & $44.22 * * *$ & $-2.46 * * *$ & 0.12 & $-1.09 *$ & 0.99 \\
\hline & $(0.36)$ & $(0.58)$ & $(0.73)$ & $(0.58)$ & $(0.73)$ \\
\hline \multirow[t]{2}{*}{ Primary childcare } & $16.81 * * *$ & -0.42 & -0.01 & -0.37 & 0.03 \\
\hline & $(0.23)$ & $(0.37)$ & $(0.45)$ & $(0.37)$ & $(0.45)$ \\
\hline \multirow[t]{2}{*}{ Total childcare } & $64.86 * * *$ & $-1.91 * *$ & $-1.77 *$ & $-2.51 * * *$ & $-2.15^{* *}$ \\
\hline & $(0.47)$ & $(0.75)$ & $(0.97)$ & $(0.75)$ & $(0.97)$ \\
\hline \multirow{4}{*}{$\begin{array}{l}\text { Unpaid work inc. } \\
\text { secondary childcare } \\
\text { Total work }\end{array}$} & $92.27 * * *$ & $-3.95 * * *$ & -1.64 & $-3.23^{* *}$ & -1.18 \\
\hline & $(0.62)$ & $(1.00)$ & $(1.29)$ & $(1.00)$ & $(1.29)$ \\
\hline & $63.54 * * *$ & -0.80 & -0.83 & 0.58 & 0.04 \\
\hline & $(0.31)$ & $(0.50)$ & $(0.66)$ & $(0.50)$ & $(0.65)$ \\
\hline \multirow{3}{*}{$\begin{array}{l}\text { Total work inc. } \\
\text { secondary childcare }\end{array}$} & $111.59 * * *$ & $-2.29 * *$ & $-2.60 * *$ & $-1.56^{* *}$ & $-2.13^{* *}$ \\
\hline & $(0.46)$ & $(0.75)$ & $(0.99)$ & $(0.74)$ & $(0.98)$ \\
\hline & \multicolumn{5}{|c|}{ Fathers } \\
\hline \multirow[t]{2}{*}{ Paid work } & $40.38 * * *$ & $-2.92 * * *$ & 1.30 & $-4.48 * * *$ & 0.31 \\
\hline & $(0.44)$ & $(0.71)$ & $(0.89)$ & $(0.71)$ & $(0.90)$ \\
\hline \multirow[t]{2}{*}{ Unpaid work } & $22.65 * * *$ & 0.60 & -0.74 & $1.43 * *$ & -0.21 \\
\hline & $(0.30)$ & $(0.48)$ & $(0.64)$ & $(0.48)$ & $(0.65)$ \\
\hline \multirow[t]{2}{*}{ Primary childcare } & $7.82 * * *$ & $0.67 * *$ & 0.41 & $0.54 *$ & 0.33 \\
\hline & $(0.18)$ & $(0.30)$ & $(0.41)$ & $(0.30)$ & $(0.41)$ \\
\hline \multirow[t]{2}{*}{ Total childcare } & $38.57 * * *$ & $1.88 * *$ & -0.92 & 0.89 & -1.55 \\
\hline & $(0.46)$ & $(0.75)$ & $(0.99)$ & $(0.75)$ & $(0.99)$ \\
\hline & $53.40 * * *$ & $1.81 *$ & $-2.06 *$ & $1.78^{*}$ & $-2.09 *$ \\
\hline secondary childcare & $(0.58)$ & $(0.93)$ & $(1.23)$ & $(0.93)$ & $(1.23)$ \\
\hline Total work & $63.03 * * *$ & $-2.32 * * *$ & 0.56 & $-3.05 * * *$ & 0.10 \\
\hline & $(0.37)$ & $(0.59)$ & $(0.75)$ & $(0.59)$ & $(0.76)$ \\
\hline Total work inc. & $93.77 * * *$ & -1.11 & -0.76 & $-2.70 * * *$ & $-1.78^{*}$ \\
\hline secondary childcare & $(0.42)$ & $(0.68)$ & $(0.92)$ & $(0.68)$ & $(0.92)$ \\
\hline
\end{tabular}

Notes The sample consists of 17,193 mothers and 15,502 fathers with children younger than 13. Standard errors are in parentheses. $* * * * *, *$ denote statistical significance at the 1,5 , and 10 percent levels, respectively. See notes to Table 2 for column definitions. 
The effects of the recession and the recovery are presented in columns 4 and 5. During the recession, there was a large (3.4 hours per week) narrowing of the gap in the time spent providing total (primary and secondary) childcare. As expected, only a small portion (0.92 hour per week) of this decline was due to a reduction in the time spent providing primary childcare. The remaining decline - of 2.48 hours - was due to the decline in the gap in time spent providing secondary childcare. The narrowing of the gender childcare gap owed to mothers reducing their total childcare hours (predominantly secondary care) by 2.5 hours per week, while fathers stepped in to pick up an average of only half an hour of additional primary childcare hours during the recession. (The small increase in total childcare by fathers is only weakly estimated.) These results suggest a deficit in secondary care for young children emerged during the recession and this deficit did not close during the recovery, as mothers reduced their secondary care hours by an additional 2.2 hours per week. In general, the small magnitudes and lack of statistical precision in the gender gaps during the recovery (top panel, column 5) suggest that the changes during the recession settled for this group of parents. Notably, when secondary childcare is accounted for, the Great Recession's lasting effect (as of the end of 2012) was a narrowing of the gender gap in unpaid work (by 5 hours), which was accompanied by the decline in gender gap in paid work hours (by 6.2 hours).

\section{SUMMARY AND CONCLUSION}

Using data from the American Time Use Survey for 2003-2012 this study provided a comprehensive account of the changes in time use patterns of mothers and fathers during the 2007-09 recession and its aftermath. The analysis contributes to the nuanced analyses of the employment outcomes of the Great Recession that have challenged the mancession narrative that focuses on losses experienced by men. Building on a small number of gendered analyses of the Great Recession that focus on changes in gendered time use in unpaid activities this paper has shown the impacts of the recession that go much further than the labor market. Focusing on cohabitating parents, we showed that not only did mothers experience the recession as an increase in their labor market hours (or entry into the labor force) in order to defend the family income levels in the face of increased male unemployment, but also these changes spilled over into the time spent on unpaid activities, both work and nonwork. 
We showed that the gender difference in the unpaid work burden declined as fathers allocated some of their foregone market hours to unpaid work, which mothers gave up in order to take on more paid work. Childcare was the main activity where household level adjustments took place. During the recession, fathers whose paid work hours declined increased the time they spent providing primary childcare, while mothers protected their primary childcare time, despite the increase in their paid work burden. As fathers took on childcare, the gender difference in unpaid work hours narrowed. During recovery, as mothers' labor market hours declined and unemployment rate increased, the time they spent on housework increased and the gender division of unpaid work hours reverted to the prerecession pattern.

Iso-work did not hold over the course of the 2003-2012 business cycle for mothers and fathers: Before the recession, mothers' total work burden was nearly an hour and a half more per week compared to fathers. The recession increased mothers' total work burden relative to fathers, primarily as fathers' paid work hours declined and there was only limited compensating increase in the unpaid work hours of fathers. Stagnant US earnings might have constrained mothers' ability to negotiate reallocation of tasks in the household, thereby slowing the convergence in unpaid work burden during the recession. The perception of the recession as a temporary event may have also dampened gender substitution in unpaid tasks. In addition, the gender-asymmetric recovery in the job market after the official end of the recession in June 2009 may have reduced the pressures for adjustment in the household. During the recovery, there was no notable change in total workloads, once the gender gap widened during the recession. The reversals in mothers' labor market status during the recovery likely weakened any shift in the gender division of unpaid labor. With increasing proportions of mothers out of the labor force or unemployed and employed mothers spending fewer hours in the labor market, as indicated in Table 1, the pressure for greater sharing of household tasks will likely have diminished. And, as the recovery continued in 2013 and 2014, the gender gap in total work burden might have gone back to its prerecession level.

Another contribution of this study is to incorporate secondary childcare data from ATUS to examine the recession's effects using a more comprehensive measure of childcare. We showed that the experience of parents of young children (age 12 or younger) was similar to that of the mothers and fathers in the full sample in terms of the impact of the recession on paid work hours and the time spent on primary childcare. We showed that mothers of young children, whose paid work hours increased, protected their primary childcare time but reduced the time 
they spent providing secondary childcare. In the absence of mothers, fathers took on some secondary childcare. Prior to the recession, this group of parents had an equitable sharing of total workload, when only primary childcare is considered. When secondary childcare time is included, however, mothers had a considerably heavier total workload compared to fathers. The recession further increased the relative workload of mothers, despite the relative and absolute increases in fathers' secondary childcare time. During recovery, the gender gap in the time spent on primary and secondary childcare stayed close to its recessionary period level, while the trends in paid and unpaid work hours were reversed as job recovery began for fathers.

Prior to the recession, in the early 2000s, mothers' labor force participation had declined, reflecting the constraints mothers, especially mothers of younger children, face in work-life balance. Feminist economists have long advocated for policies to encourage both women and men to combine paid work with family care (Folbre and Nelson 2000). In the aftermath of the Great Recession, feminist studies also argued for public investment in care, in particular direct investment in localized, community-based social care services of home-based health care and early childhood development (Antonopoulos et al. 2013). Through a simulation exercise, Antonopoulos et al. (2013) find that investment in social care creates considerably more jobs than its alternatives of investment in infrastructure and green energy. It also leads to more equitable outcomes, creating more jobs for low-income households and women.

Since African-American and Hispanic men and single mothers have suffered more job losses than their respective counterparts during the recession, the analysis of time-use of parents in these groups during the expansion-recession-recovery cycle of 2003-2012 would contribute to a more differentiated understanding of the outcomes of the Great Recession. 
Appendix Table 1 Characteristics of Mothers and Fathers in the Sample, 2003-12

\begin{tabular}{|c|c|c|c|c|c|c|c|c|c|}
\hline & \multicolumn{4}{|c|}{ Mothers } & \multicolumn{5}{|c|}{ Fathers } \\
\hline & & $\begin{array}{c}2003-12 \\
\text { average } \\
(1)\end{array}$ & $\begin{array}{l}\text { Prerecession } \\
\text { (2) }\end{array}$ & $\begin{array}{l}\text { Recession } \\
\text { (3) }\end{array}$ & $\begin{array}{l}\text { Recovery } \\
\text { (4) }\end{array}$ & $\begin{array}{c}2003-12 \\
\text { average } \\
(1)\end{array}$ & $\begin{array}{l}\text { Prerecession } \\
\text { (2) }\end{array}$ & $\begin{array}{l}\text { Recession } \\
\text { (3) }\end{array}$ & $\begin{array}{l}\text { Recovery } \\
\text { (4) }\end{array}$ \\
\hline & Age (years) & 38 & 37 & 38 & 39 & 40 & 39 & & 40 \\
\hline & Usual weekly earnings $^{2}(\$)$ & 704.11 & 641.16 & 741.40 & 805.53 & $1,071.78$ & $1,015.38$ & & $1,109.86$ \\
\hline \multicolumn{10}{|c|}{$\begin{array}{r}\text { Share of respondents by demographic and } \\
\text { household characteristics } 3(\%)\end{array}$} \\
\hline Race/ethnicity & AfricanAmerican & 8 & 8 & 8 & 7 & 9 & 9 & 9 & 8 \\
\hline \multirow{5}{*}{ Age group } & Hispanic & 21 & 20 & 22 & 23 & 22 & 22 & 22 & 23 \\
\hline & Ages 18-24 & 5 & 6 & 4 & 4 & 3 & 3 & 2 & 3 \\
\hline & Ages $25-34$ & 31 & 33 & 31 & 29 & 26 & 27 & 26 & 24 \\
\hline & Ages $35-44$ & 41 & 41 & 41 & 42 & 40 & 41 & 39 & 39 \\
\hline & Ages 45-54 & 19 & 18 & 20 & 21 & 25 & 24 & 25 & 27 \\
\hline \multirow{5}{*}{ Education } & Ages $55-65$ & 4 & 3 & 4 & 4 & 6 & 5 & 7 & 7 \\
\hline & $<$ High school diploma & 13 & 13 & 13 & 10 & 15 & 16 & 14 & 14 \\
\hline & High school & 28 & 30 & 26 & 27 & 30 & 30 & 30 & 29 \\
\hline & Some college & 25 & 25 & 24 & 24 & 23 & 23 & 23 & 23 \\
\hline & BA or more & 35 & 32 & 37 & 39 & 33 & 31 & 33 & 34 \\
\hline Age of the & Younger than age 3 & 31 & 32 & 31 & 30 & 31 & 32 & 31 & 29 \\
\hline \multirow[t]{4}{*}{ youngest child } & Ages 3-5 & 19 & 19 & 19 & 20 & 19 & 19 & 20 & 19 \\
\hline & Ages 6-9 & 19 & 19 & 20 & 19 & 19 & 19 & 19 & 20 \\
\hline & Ages $10-13$ & 16 & 17 & 15 & 17 & 16 & 16 & 16 & 17 \\
\hline & Ages $14-17$ & 14 & 13 & 14 & 14 & 14 & 14 & 14 & 15 \\
\hline \multirow[t]{5}{*}{ No. of children } & 1 & 37 & 37 & 37 & 37 & 36 & 36 & 36 & 37 \\
\hline & 2 & 40 & 39 & 40 & 41 & 40 & 40 & 40 & 40 \\
\hline & 3 & 16 & 17 & 16 & 15 & 17 & 17 & 16 & 17 \\
\hline & 4 & 5 & 5 & 5 & 5 & 5 & 5 & 5 & 5 \\
\hline & 5 or more & 2 & 2 & 2 & 2 & 2 & 2 & 2 & 2 \\
\hline $\mathrm{N}$ & & 16,478 & 8,851 & 4,804 & 2,823 & 14,697 & 7,812 & 4,293 & 2,592 \\
\hline
\end{tabular}

Notes All observations are weighted by ATUS sampling weights.

${ }^{1}$ Weekly nominal earnings of employed mothers and fathers.

${ }^{2}$ The percentage of mothers and fathers with selected individual and household characteristics. 
Appendix Table 2 Trend Analysis of Gender Differences in Time Allocation for Parents with Children Younger than 13, 2003-12 (Weekly Hours)

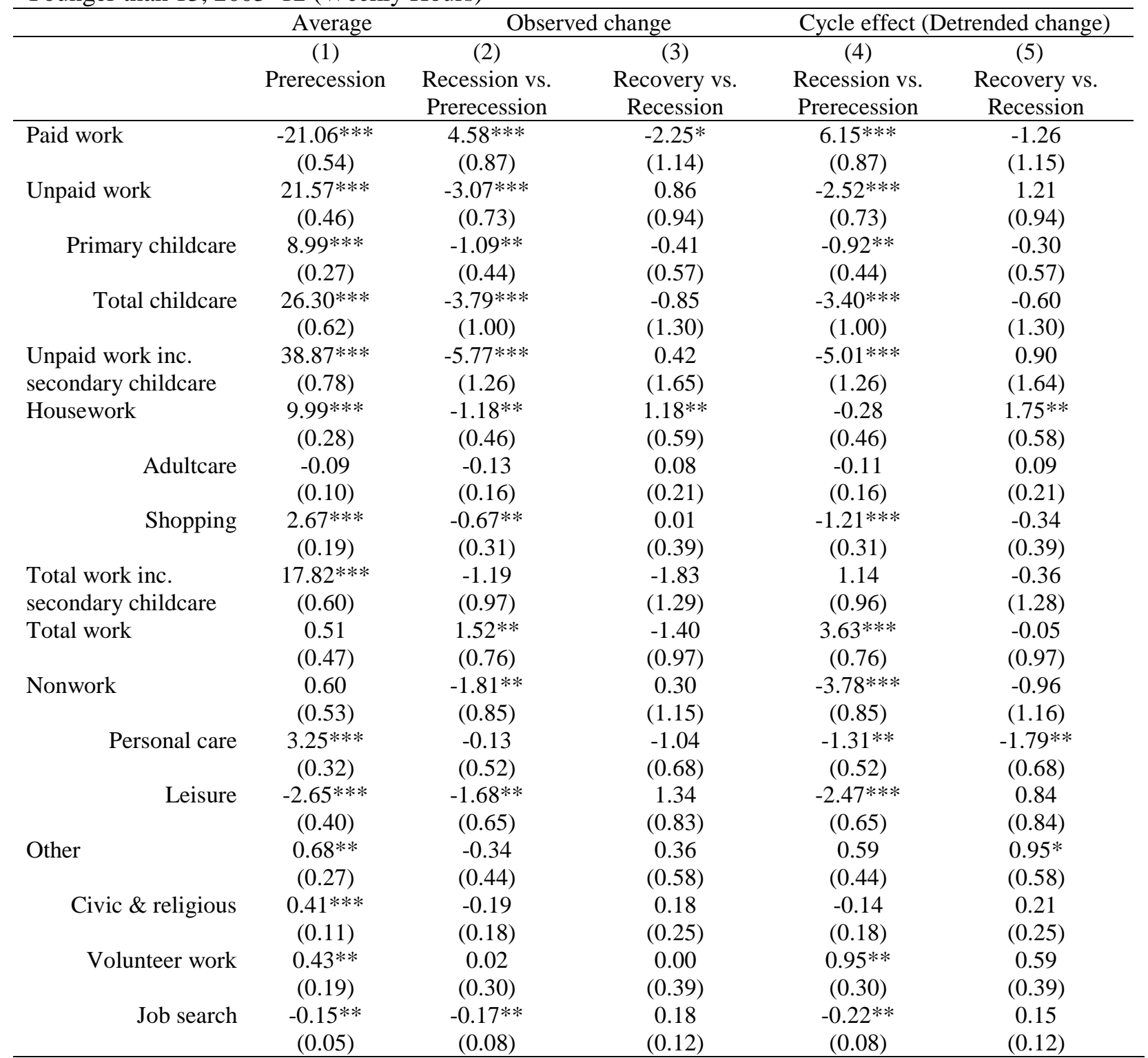

Notes The sample consists of 17,193 mothers and 15,502 fathers with children younger than 13. Standard errors are in parentheses. $* * *, * *, *$ denote statistical significance at the 1,5 , and 10 percent levels, respectively. See notes to Table 2 for column definitions. 
Appendix Table 3 Trend Analysis of Time Allocation of Mothers with Children Younger than 13, 2003-12 (Weekly Hours)

\begin{tabular}{|c|c|c|c|c|c|}
\hline & \multirow{3}{*}{$\begin{array}{c}\text { Average } \\
\text { (1) } \\
\text { Prerecession }\end{array}$} & \multicolumn{2}{|c|}{ Observed change } & \multicolumn{2}{|c|}{ Cycle effect (Detrended change) } \\
\hline & & (2) & (3) & (4) & $(5)$ \\
\hline & & $\begin{array}{l}\text { Recession vs. } \\
\text { Prerecession }\end{array}$ & $\begin{array}{l}\text { Recovery vs. } \\
\text { Recession }\end{array}$ & $\begin{array}{l}\text { Recession vs. } \\
\text { Prerecession }\end{array}$ & $\begin{array}{l}\text { Recovery vs. } \\
\text { Recession }\end{array}$ \\
\hline Paid work & $\begin{array}{c}19.32 * * * \\
(036)\end{array}$ & $\begin{array}{l}1.66^{* *} \\
(0.58)\end{array}$ & $\begin{array}{l}-0.95 \\
(0.80)\end{array}$ & $\begin{array}{c}1.67 * * \\
(0.58)\end{array}$ & $\begin{array}{l}-0.95 \\
(0.80)\end{array}$ \\
\hline Unpaid work & $\begin{array}{c}44.22 * * * \\
(0.36)\end{array}$ & $\begin{array}{c}-2.46^{* * * *} \\
(0.58)\end{array}$ & $\begin{array}{c}0.12 \\
(0.73)\end{array}$ & $\begin{array}{l}-1.09^{*} \\
(0.58)\end{array}$ & $\begin{array}{c}0.99 \\
(0.73)\end{array}$ \\
\hline Primary childcare & $\begin{array}{c}16.81 * * * \\
(0.23)\end{array}$ & $\begin{array}{l}-0.42 \\
(0.37)\end{array}$ & $\begin{array}{l}-0.01 \\
(0.45)\end{array}$ & $\begin{array}{l}-0.37 \\
(0.37)\end{array}$ & $\begin{array}{c}0.03 \\
(0.45)\end{array}$ \\
\hline Total childcare & $\begin{array}{c}64.86 * * * \\
(0.47)\end{array}$ & $\begin{array}{c}-1.91 * * \\
(0.75)\end{array}$ & $\begin{array}{l}-1.77 * \\
(0.97)\end{array}$ & $\begin{array}{c}-2.51 * * * \\
(0.75)\end{array}$ & $\begin{array}{c}-2.15^{* *} \\
(0.97)\end{array}$ \\
\hline $\begin{array}{l}\text { Unpaid work inc. } \\
\text { secondary childcare }\end{array}$ & $\begin{array}{l}92.27 * * * \\
(0.62)\end{array}$ & $\begin{array}{c}-3.95 * * * \\
(1.00)\end{array}$ & $\begin{array}{l}-1.64 \\
(1.29)\end{array}$ & $\begin{array}{c}-3.23^{* *} \\
(1.00)\end{array}$ & $\begin{array}{l}-1.18 \\
(1.29)\end{array}$ \\
\hline Housework & $\begin{array}{c}19.21 * * * \\
(0.23)\end{array}$ & $\begin{array}{c}-1.07 * * \\
(0.37)\end{array}$ & $\begin{array}{c}0.65 \\
(0.47)\end{array}$ & $\begin{array}{l}-0.20 \\
(0.37)\end{array}$ & $\begin{array}{l}1.21 * * \\
(0.47)\end{array}$ \\
\hline Adultcare & $\begin{array}{c}0.99 * * * \\
(0.06)\end{array}$ & $\begin{array}{l}-0.13 \\
(0.10)\end{array}$ & $\begin{array}{l}-0.19 \\
(0.12)\end{array}$ & $\begin{array}{c}0.39 * * * \\
(0.10)\end{array}$ & $\begin{array}{c}0.14 \\
(0.12)\end{array}$ \\
\hline Shopping & $\begin{array}{c}7.21 * * * \\
(0.14)\end{array}$ & $\begin{array}{c}-0.84 * * * \\
(0.23)\end{array}$ & $\begin{array}{l}-0.34 \\
(0.28)\end{array}$ & $\begin{array}{c}-0.90 * * * \\
(0.23)\end{array}$ & $\begin{array}{l}-0.38 \\
(0.28)\end{array}$ \\
\hline $\begin{array}{l}\text { Total work inc. } \\
\text { secondary childcare }\end{array}$ & $\begin{array}{c}111.59 * * * \\
(0.46)\end{array}$ & $\begin{array}{l}-2.29 * * \\
(0.75)\end{array}$ & $\begin{array}{l}-2.60 * * \\
(0.99)\end{array}$ & $\begin{array}{l}-1.56 * * \\
(0.74)\end{array}$ & $\begin{array}{l}-2.13 * * \\
(0.98)\end{array}$ \\
\hline Total work & $\begin{array}{c}63.54 * * * \\
(0.31)\end{array}$ & $\begin{array}{l}-0.80 \\
(0.50)\end{array}$ & $\begin{array}{l}-0.83 \\
(0.66)\end{array}$ & $\begin{array}{c}0.58 \\
(0.50)\end{array}$ & $\begin{array}{c}0.04 \\
(0.65)\end{array}$ \\
\hline Nonwork & $\begin{array}{l}100.11 * * * \\
(0.38)\end{array}$ & $\begin{array}{l}-0.16 \\
(0.61)\end{array}$ & $\begin{array}{l}-0.55 \\
(0.90)\end{array}$ & $\begin{array}{l}-0.88 \\
(0.62)\end{array}$ & $\begin{array}{l}-1.00 \\
(0.90)\end{array}$ \\
\hline Personal care & $\begin{array}{c}64.22 * * * \\
(0.22)\end{array}$ & $\begin{array}{c}0.17 \\
(0.36)\end{array}$ & $\begin{array}{l}-0.56 \\
(0.52)\end{array}$ & $\begin{array}{l}-0.15 \\
(0.36)\end{array}$ & $\begin{array}{l}-0.77 \\
(0.52)\end{array}$ \\
\hline Leisure & $\begin{array}{l}35.89 * * * \\
(0.29)\end{array}$ & $\begin{array}{l}-0.34 \\
(0.46)\end{array}$ & $\begin{array}{c}0.01 \\
(0.62)\end{array}$ & $\begin{array}{l}-0.73 \\
(0.46)\end{array}$ & $\begin{array}{l}-0.24 \\
(0.62)\end{array}$ \\
\hline Other & $\begin{array}{c}4.68 * * * \\
(0.20)\end{array}$ & $\begin{array}{l}0.05 \\
(0.32)\end{array}$ & $\begin{array}{l}-0.04 \\
(0.41)\end{array}$ & $\begin{array}{l}0.86^{* *} \\
(0.32)\end{array}$ & $\begin{array}{c}0.47 \\
(0.41)\end{array}$ \\
\hline Civic \& religious & $\begin{array}{l}2.08 * * * \\
(0.08)\end{array}$ & $\begin{array}{c}0.03 \\
(0.13)\end{array}$ & $\begin{array}{c}0.13 \\
(0.17)\end{array}$ & $\begin{array}{c}0.21 \\
(0.13)\end{array}$ & $\begin{array}{c}0.24 \\
(0.17)\end{array}$ \\
\hline Volunteer work & $\begin{array}{c}2.55 * * * \\
(0.13)\end{array}$ & $\begin{array}{l}-0.03 \\
(0.22)\end{array}$ & $\begin{array}{l}-0.19 \\
(0.28)\end{array}$ & $\begin{array}{c}0.59 * * \\
(0.22)\end{array}$ & $\begin{array}{c}0.21 \\
(0.28)\end{array}$ \\
\hline Job search & $\begin{array}{c}0.05 * * \\
(0.02)\end{array}$ & $\begin{array}{l}0.05^{*} \\
(0.03)\end{array}$ & $\begin{array}{c}0.02 \\
(0.04)\end{array}$ & $\begin{array}{c}0.06 * * \\
(0.03)\end{array}$ & $\begin{array}{c}0.02 \\
(0.04)\end{array}$ \\
\hline
\end{tabular}

Notes See notes to Table 5 . 
Appendix Table 4 Trend Analysis of Time Allocation of Fathers with Children Younger than 13, 2003-12 (Weekly Hours)

\begin{tabular}{|c|c|c|c|c|c|}
\hline & \multirow{3}{*}{$\begin{array}{c}\text { Average } \\
(1) \\
\text { Prerecession }\end{array}$} & \multicolumn{2}{|c|}{ Observed change } & \multicolumn{2}{|c|}{ Cycle effect (Detrended change) } \\
\hline & & (2) & (3) & (4) & $(5)$ \\
\hline & & $\begin{array}{l}\text { Recession vs. } \\
\text { Prerecession }\end{array}$ & $\begin{array}{l}\text { Recovery vs. } \\
\text { Recession }\end{array}$ & $\begin{array}{l}\text { Recession vs. } \\
\text { Prerecession }\end{array}$ & $\begin{array}{l}\text { Recovery vs. } \\
\text { Recession }\end{array}$ \\
\hline \multirow[t]{2}{*}{ Paid work } & $40.38 * * *$ & $-2.92 * * *$ & 1.30 & $-4.48 * * *$ & 0.31 \\
\hline & $(0.44)$ & $(0.71)$ & $(0.89)$ & $(0.71)$ & $(0.90)$ \\
\hline \multirow[t]{2}{*}{ Unpaid work } & $22.65 * * *$ & 0.60 & -0.74 & $1.43 * *$ & -0.21 \\
\hline & $(0.30)$ & $(0.48)$ & $(0.64)$ & $(0.48)$ & $(0.65)$ \\
\hline \multirow[t]{2}{*}{ Primary childcare } & $7.82 * * *$ & $0.67 * *$ & 0.41 & $0.54 *$ & 0.33 \\
\hline & $(0.18)$ & $(0.30)$ & $(0.41)$ & $(0.30)$ & $(0.41)$ \\
\hline \multirow[t]{2}{*}{ Total childcare } & $38.57 * * *$ & $1.88 * *$ & -0.92 & 0.89 & -1.55 \\
\hline & $(0.46)$ & $(0.75)$ & $(0.99)$ & $(0.75)$ & $(0.99)$ \\
\hline \multirow{4}{*}{$\begin{array}{l}\text { Unpaid work inc. } \\
\text { secondary childcare } \\
\text { Housework }\end{array}$} & $53.40 * * *$ & $1.81 *$ & $-2.06^{*}$ & $1.78^{*}$ & $-2.09 *$ \\
\hline & $(0.58)$ & $(0.93)$ & $(1.23)$ & $(0.93)$ & $(1.23)$ \\
\hline & $19.21 * * *$ & $-1.07 * *$ & 0.65 & -0.20 & $1.21 * *$ \\
\hline & $(0.23)$ & $(0.37)$ & $(0.47)$ & $(0.37)$ & $(0.47)$ \\
\hline \multirow[t]{2}{*}{ Adultcare } & $1.08^{* * * *}$ & 0.00 & -0.27 & $0.50 * * *$ & 0.05 \\
\hline & $(0.08)$ & $(0.13)$ & $(0.17)$ & $(0.13)$ & $(0.17)$ \\
\hline \multirow[t]{2}{*}{ Shopping } & $4.54 * * *$ & -0.17 & -0.35 & 0.31 & -0.04 \\
\hline & $(0.13)$ & $(0.21)$ & $(0.28)$ & $(0.21)$ & $(0.28)$ \\
\hline \multirow{4}{*}{$\begin{array}{l}\text { Total work inc. } \\
\text { secondary childcare } \\
\text { Total work }\end{array}$} & $93.77 * * *$ & -1.11 & -0.76 & $-2.70 * * *$ & $-1.78 *$ \\
\hline & $(0.42)$ & $(0.68)$ & $(0.92)$ & $(0.68)$ & $(0.92)$ \\
\hline & $63.03 * * *$ & $-2.32 * * *$ & 0.56 & $-3.05 * * *$ & 0.10 \\
\hline & $(0.37)$ & $(0.59)$ & $(0.75)$ & $(0.59)$ & $(0.76)$ \\
\hline \multirow[t]{2}{*}{ Nonwork } & $99.51 * * *$ & $1.64 * *$ & -0.84 & $2.90 * * *$ & -0.05 \\
\hline & $(0.38)$ & $(0.61)$ & $(0.76)$ & $(0.61)$ & $(0.77)$ \\
\hline \multirow[t]{2}{*}{ Personal care } & $60.97 * * *$ & 0.30 & 0.49 & $1.16^{* *}$ & $1.03 * *$ \\
\hline & $(0.22)$ & $(0.36)$ & $(0.44)$ & $(0.36)$ & $(0.44)$ \\
\hline \multirow[t]{2}{*}{ Leisure } & $38.54 * * *$ & $1.34 * *$ & $-1.33 * *$ & $1.74 * * *$ & $-1.08 *$ \\
\hline & $(0.31)$ & $(0.51)$ & $(0.65)$ & $(0.51)$ & $(0.65)$ \\
\hline \multirow[t]{2}{*}{ Other } & $4.00 * * *$ & 0.39 & -0.40 & 0.27 & -0.48 \\
\hline & $(0.19)$ & $(0.31)$ & $(0.43)$ & $(0.31)$ & $(0.43)$ \\
\hline \multirow[t]{2}{*}{ Civic \& religious } & $1.67 * * *$ & $0.22 *$ & -0.05 & $0.35 * *$ & 0.03 \\
\hline & $(0.08)$ & $(0.13)$ & $(0.19)$ & $(0.13)$ & $(0.19)$ \\
\hline \multirow[t]{2}{*}{ Volunteer work } & $2.12^{* * *}$ & -0.05 & -0.19 & -0.36 & -0.38 \\
\hline & $(0.13)$ & $(0.22)$ & $(0.29)$ & $(0.22)$ & $(0.29)$ \\
\hline \multirow[t]{2}{*}{ Job search } & $0.20 * * *$ & $0.22 * *$ & -0.17 & $0.27 * * *$ & -0.13 \\
\hline & $(0.05)$ & $(0.08)$ & $(0.11)$ & $(0.08)$ & $(0.11)$ \\
\hline
\end{tabular}

Notes See Notes to Table 5. 


\section{Appendix 1 Sensitivity Tests}

To control for possible changes in the sample composition of the ATUS over time that could potentially explain the changes in gender differences in paid and unpaid work hours across time periods, we regress the gender difference in paid work and unpaid work hours on the recession period (December 2007-December 2010), dummy recovery period (January 2011-December 2012), dummy and demographic controls that measure the proportion of the population in the following categories: age groups (via five year age groups of 18-24, 25-34, 35-44, 45-54, 5565 ), the educational distribution of mothers and fathers (via four education groups of less than 12 years of schooling, high school diploma, some college and college or more), the race and the ethnicity distribution (using the shares of mothers and fathers who are African-American and Hispanic), the distribution by number of children in the household (via four groups of 1 child, 2 , $3,4,5$ or more children), and the distribution of the sample by the age of children in the household (via five age categories of younger than age -3, 3-5, 6-, 10-13, 14-17). Since the unconditional differences reported in columns 2 and 3 of Table 2 are also weighted using the harmonized individual weights provided by the ATUS for each year, controlling for demographics only has small effects on the estimated time series changes in the gender gap in paid and unpaid work hours. For instance, the observed change in the gender gap in paid work hours reported in column 2 of Table 2 of 3.7 hours per week is 3.4 hours per week after controlling for demographics. The 0.3-hour difference between the two estimates is statistically insignificant, according to t-test results. The gender gap in unpaid work hours of 2.4 hours per week reported in column 2 of Table 2 is 2.1 hours per week, controlling for demographics. The difference between the two estimates is also insignificant. We repeat this exercise for the changes in the gender differences in paid and unpaid work hours during Recovery and obtain the same results: the differences between the estimates reported in Table 2 are not statistically significantly different than the estimates when we control for demographics. 


\section{Notes}

${ }^{1}$ Evidence from other parts of the world also indicates gendered outcomes of the Great Recession, both in productive and reproductive activities. Kaya Bahce and Memis (2013) find that a rise in spouse's unemployment risk disproportionately increased women's paid and unpaid labor time in Turkey. In China, women and men were laid off at roughly equal rates after the recession (Zhi et al. 2013). The austerity measures and cuts in social spending following the crisis increased vulnerability of women and children in a large group of developing economies (Ortiz and Cummins 2013).

${ }^{2}$ Aguiar et al. (2013) provide a comprehensive assessment of the reallocation of time spent by women and men in US labor markets with the recession, but they do not examine how women fared relative to men.

${ }^{3}$ A similar argument has been made in the US popular press (BLS 2011; Konigsberg 2011). Accordingly, the total work hours difference between married men and women who were employed full time and did not have children (under 18 years of age) dropped to 8 minutes per day in 2010, which suggests that employed mothers' disproportionate total work burden - that is, the double day - may be a thing of the past. Even having children amounted to what Konigsberg (2011) deemed a fairly small difference in total work of 20 minutes more per day for full-time employed mothers than fathers.

${ }^{4}$ Connelly and Kimmel (2007) developed strategies to match mothers and fathers with time diaries to predict couples in the ATUS sample that future research can utilize to examine the impact of the recession on within-household gender division of labor.

${ }^{5}$ An additional reason for focusing on cohabiting mothers and fathers is that the labor force participation (LFP) patterns of single mothers diverged from those of married mothers long before the recession (Hoffman 2009).

${ }^{6}$ The employment status changes are sensitive to the dating of the recession. If intensity of job losses is used to date the recession and 2008 is considered part of the prerecession period, the added-worker effect disappears and, rather than rising, full-time employed mothers' paid work hours declines. These results are available upon request.

7 The results for other time use categories are reported in Appendix Tables 2-4. There are quite a few interesting results in Table 5. For instance, compared to the full sample, the gender differences in paid and unpaid work hours of parents of younger children are more pronounced, likely reflecting greater constraints mothers of younger children face in terms of labor force participation. 


\section{References}

Aguiar, M. \& Hurst, E. (2007). "Measuring Trends in Leisure: The Allocation of Time Over Five Decades,” Quarterly Journal of Economics, 122(3), 969-1006.

Aguiar, Mark, Hurst, E. Hurst, and Karabarbounis, L. (2013). "Time Use During the Great Recession," American Economic Review, 103(5), 1664-1696.

Albelda, R. (2014). “Gender Impacts of the 'Great Recession' in the United States," In M. Karamessini \& J. Rubery (Eds.), Women and Austerity: The Economic Crisis and the Future of Gender Equality (pp. 82-101). New York: Routledge.

Antonopoulos, R., Kim, K., Masterson, T. \& Zacharias, A. (2013). "Investing in Care in the Midst of a Crisis: A Strategy for Effective and Equitable Job Creation," In R. Antonopoulos (Ed.), Gender Perspectives and Gender Impacts of the Global Economic Crisis (pp. 49-72). New York: Routledge.

Arestis, P., Charles, A. \& Fontana, G. (2013). "Financialization, the Great Recession, and the Stratification of the US Labor Market," Feminist Economics, 19(3), 152-180.

Benería, L. \& Feldman, S. (eds.) (1992). “Unequal Burden: Economic Crises, Persistent Poverty, and Women's Work," Boulder, CO: Westview Press.

Berik, G. \& Kongar, E. (2013). "Time Allocation of Married Mothers and Fathers in Hard Times: The 2007-09 US Recession," Feminist Economics, 19(3), 208-237.

Bianchi, S. M. (2011). "Family Change and Time Allocation in American Families," The ANNALS of the American Academy of Political and Social Science, 638(1), 21-44.

Bianchi, S. M., Robinson, J. P. \& Milkie, M. (2006). "Changing Rhythms of American Family Life," New York: Russell Sage.

Bianchi, S. M., Wight, V. R \& Raley, S. B. (2005). "Maternal Employment and Family Caregiving: Rethinking Time with Children in the ATUS," Paper presented at the American Time Use Survey (ATUS) Early Results Conference, Bethesda, Maryland.

Blau, F. D. \& Kahn, L. M. (2007). "Changes in the Labor Supply Behavior of Married Women: 1980-2000,” Journal of Labor Economics, 25(3), 393-438.

Bureau of Labor Statistics (BLS). (2011). Table 8. Time Spent in Primary Activities for the Civilian Population 18 Years and Over by Employment Status, Presence and Age of Youngest Household Child, and Sex, 2011 Annual Averages.

http://www.bls.gov/news.release/atus.t08.htm. Accessed June 1, 2014.

Bureau of Labor Statistics (BLS). (2012). Employment Characteristics of Families. Archived News Releases. http://www.bls.gov/schedule/archives/all_nr.htm\#FAMEE. 
Bureau of Labor Statistics (BLS). (2013a). Women in the Labor Force: A Databook.

Report 1040. Accessed electronically at http://www.bls.gov/cps/wlf-databook2012.pdf (03/21/2014).

Bureau of Labor Statistics (BLS). (2013b). Labor Force Statistics from the Current Population Survey. http://data.bls.gov/timeseries/LNS14000000.

Burda, M. \&. Hamermesh, D. S. (2010). "Unemployment, Market Work, and Household Production,” Economics Letters, 107(2), 131-133.

Burda, M., Hamermesh, D. S. \& Weil, P. (2013). "Total Work and Gender: Facts and Possible Explanations," Journal of Population Economics, 26(1), 239-261.

Casper, L. \& O’Connell, M. (1998). “Work, Income, the Economy, and Married Fathers as Child-care Providers," Demography, 35(2), 243-250.

Connelly, R. \& Kimmel, J. (2007). "Spousal Influences on Parents' Non-market Time Choices," Review of Economics of the Household, 7(4), 361-394.

Connelly, R. \& Kimmel, J. (2010). "Time Use of Mothers in the United States at the Turn of the 21st Century,” Kalamazoo, MI: W. E. Upjohn Institute for Employment Research.

Corporation for National and Community Service, Office of Research and Policy

Development. (2010). "Volunteering in America (2010): National, State, and City Information," Washington, DC, Accessed electronically at http://www.nationalservice.gov/sites/default/files/documents/10_0614_via_final_issue_b rief.pdf. (03/21/2014).

Dymski, G., Hernandez, J. \& Mohanty, L. (2013). "Race, Gender, Power, and the US Subprime Mortgage and Foreclosure Crisis: A Meso Analysis," Feminist Economics, 19(3), 124151.

Elson, D. (Ed.). 1995. "Male Bias in the Development Process," Second edition, Manchester: Manchester University Press.

Elson, D. (2012). "Social Reproduction and the Global Crisis: Rapid Recovery of LongLasting Depletion?” In P. Utting, S. Razavi, \& R. V. Buchholz (Eds.), The Global Crisis and Transformative Social Change (pp. 63-80). Basingstoke: Palgrave Macmillan.

Folbre, N. (2006). "Measuring Care: Gender, Empowerment, and the Care Economy," Journal of Population Economics, 7(2), 183-199.

Folbre, N. \& Nelson, J. (2000). "For Love or Money-Or both?” Journal of Economic Perspectives, 14(4), 123-140. 
Folbre, N. \& Yoon, J. (2007). "What is Child Care? Lessons from Time-use Surveys of Major English-speaking Countries," Review of Economics of the Household, 5(3), 223-248.

Greenwood, J. \& Hercowitz, Z. (1991). "The Allocation of Capital and Time Over the Business Cycle," Journal of Political Economy, 99(6), 1188-1214.

Grown, C. and Tas, E. (2010). "Gender Equality in the U.S. Labor Markets in the 'Great Recession' of 2007-2010,” In M. A. Starr (Ed.), Consequences of Economic Downturn: Beyond the Usual Economics (pp. 167-189). New York: Palgrave Macmillan.

Guryan, J., Hurst, E. \& Kearney, M. (2008). "Parental Education and Parental Time with Children," Journal of Economic Perspectives, 22(3), 23-46.

Hartmann, H., English, A. \& Hayes, J. (2010). "Women and Men's Employment and Unemployment in the Great Recession, ” Institute for Women's Policy Research (IWPR). Working Paper C373.http://www.in.gov/icw/files/employment.pdf.

Hoffman, S. D. (2009). “The Hanging Impact of Marriage and Children on Women's Labor Force Participation," Monthly Labor Review, 132(2), 3-14.

Kalenkoski, C., Ribar, D. \& Stratton, L. (2007). “The Effect of Family Structure on Parents' Child Care Time in the United States and the United Kingdom," Review of Economics of the Household, 5(4), 353-384.

Karamessini, M. \& Rubery, J. (Eds.) (2013). "Women and Austerity: The Economic Crisis and the Future for Gender Equality," Abington: Routledge.

Kaya Bahçe, S. A. \& Memiş, E. (2013). "Estimating the Impact of the 2008-9 Economic Crisis on Work Time in Turkey. Feminist Economics, 19(3), 181-207.

Khitarishvili, T. \& Kim, K. (2014). "The Great Recession and Unpaid Work Time in the U.S.: Does Poverty Matter?" Levy Working Paper 806. http://www.levyinstitute.org/publications/the-great-recession-and-unpaid-work- timein-the-united-states-does-poverty-matter

Kimmel, J. \& Connelly, R. (2007). "Mothers' Time Choices: Caregiving, Leisure, Home Production, and Paid Work," Journal of Human Resources, 42(3), 643-661.

Konigsberg, R. D. (2011). "Chore Wars," Time Magazine, August 8. Accessed electronically at http://www.time.com/time/magazine/article/0,9171,2084582,00.html (02/03/2012).

Lagarde, C. (2010). "Women, Power and the Challenge of the Financial Crisis," New York Times: Op-Ed, May 12. Accessed electronically at http://www.nytimes.com/2010/05/11/opinion/11iht- edlagarde.html?_r=0 (07/14/2014). 
Lim, J. (2000). "The Effects of the East Asian Crisis on the Employment of Women and Men: The Philippines Case," World Development, 28(7), 1285-1306.

Mattingly, M. J. \& Smith, K. E. (2010). “Changes in Wives' Employment When Husbands Stop Working: A Recession-Prosperity Comparison," Family Relations, 59(4), 343357.

Morrill, M. S. \& Pabilonia, S. W. (2012). "What Effects do Macroeconomic Conditions Have on Families’ Time Together?” Working Paper. http://www.sole-jole.org/12202.pdf.

Nock, S L. \& Kingston, P. W. 1988. "Time with Children: The Impact of Couples' Work-Time Commitments," Social Forces 67: 59-85.

Ortiz, I. \& Cummins, M. (2013). "Austerity Measures in Developing Countries: Public Expenditure Trends and the Risks to Children and Women," Feminist Economics, 19(3): 55-81.

Perry, M. J. (2010). “The Great Mancession of (2008-2009)," Statement before the House Ways and Means Committee, Subcommittee on Income Security and Family Support, July 17, 2010. http://www.aei.org/speech/100152.

Pierret, C. R. (2006). "The 'Sandwich Generation': Women Caring for Parents and Children," Monthly Labor Review, September, 3-9.

Prügl, E. (2012). "If Lehman Brothers had been Lehman Sisters...: Gender and Myth in the Aftermath of the Financial Crisis," International Political Sociology, 6(1), 21-35.

Ramey, V. A. (2008). "Time Spent in Home Production in the 20th Century: New Estimates from Old Data,” NBER Working Paper 13985.

Ramey, V. A. \& Francis, N. (2009). “A Century of Work and Leisure,” American Economic Journal: Macroeconomics, 1(2), 189-224.

Rubery, J. (Ed.). (1988). "Women and Recession,” London: Routledge.

Şahin, A. Song, J. \& Hobijn, B. (2010). "The Unemployment Gender Gap During the 2007 Recession," Current Issues in Economics and Finance, 16(2), 1-7.

Starr, M.A. (2014). “Gender, Added-worker Effects, and the 2007-2009 Recession: Looking Within the Household," Review of Economics of the Household, 12, 209235.

Thompson, D. (2009). “It's not Just a Recession. It's a Mancession!” The Atlantic, July 9, 2009. Accessed electronically at www.theatlantic.com/buisness/2009/07/its-not- just-arecession-its-a-mancession/20991 (07/22/2014). 
US Census Bureau. (2010). "Who’s Minding the Kids? Child Care Arrangements: Spring 2005/Summer 2006," Household Economic Studies P70-121, Current Population Reports, US Census Bureau.

Walby, S. (2009). “Gender and the Financial Crisis," Paper for UNESCO Project on 'Gender and the Financial Crisis.' Accessed electronically at http://www.lancaster.ac.uk/fass/doc_library/sociology/Gender_and_financial_cris is_Sylvia_Walby.pdf (07/01/2014).

Zhi, H., Huang, Z. Huang, J., Rozelle, S. D. \& Mason, A. D. (2013). "Impact of the Global Financial Crisis in Rural China: Gender, Off-farm Employment, and Wages," Feminist Economics, 19(3), 238-266. 